\title{
Gloriosa superba and Colchicum autumnale multi- tissue transcriptome analysis for colchicine pathway and rhizome development candidate gene identification
}

John Samuel Bass

University of Houston

David R. Gang

Washington State University

Toni M. Kutchan

Donald Danforth Plant Science Center

Ganapathy Sivakumar ( $\sim$ sganapa3@central.uh.edu )

University of Houston https://orcid.org/0000-0002-9420-4834

Research article

Keywords: Biorhizome, bioinformatics, biomanufacturing, biomedicine, synthetic biotechnology

Posted Date: May 14th, 2019

DOl: https://doi.org/10.21203/rs.2.9594/v1

License: (c) (i) This work is licensed under a Creative Commons Attribution 4.0 International License.

Read Full License 


\section{Abstract}

Background The continued emergence of side-effects caused by synthetic drugs underscores the need for plant-based drugs in human medicine. Medicinal rhizomatous crops are a "goldmine for modern drugs", and include such species as Gloriosa superba L. and Colchicum autumnale L., the producers of colchicine, a plant-based medicine. The natural isomer of bioactive colchicine is used to effectively treat major diseases such as cancer, cardiovascular disease, and gout. The medicinal properties of colchicine are well characterized, however, almost nothing is known about its biosynthesis. The paucity of information on the colchicine biosynthetic pathway is a significant barrier to biomanufacturing of this biomedicine. A comparative transcriptome study of $\mathrm{G}$. superba and $\mathrm{C}$. autumnale serves as a sequence resource to aid with identification of this biomedicine pathway and rhizome development genes for synthetic biotechnology toolbox, which will enable improved colchicine biomanufacturing. Result Transcriptomes of two colchicine synthesizing monocots $\mathrm{G}$. superba and $\mathrm{C}$. autumnale were interrogated to identify putative CDNAs encoding enzymes and transcription factors involved in the colchicine biosynthetic pathway and rhizome development. Mining of the transcriptomes using Blast2GO led to the identification from G. superba and C. autumnale, respectively, of 20 and 29 candidate colchicine biosynthetic genes N-methyltransferases, 3-0-methyltransferases, cytochrome P450s, a class that could catalyze several steps in the pathway, and N-acetyltransferases. Similarly, 19 and 15 candidate rhizome developmental genes, which belongs to several classes including GIGANTEA, CONSTANS, Phytochrome B, Sucrose Synthase), Flowering Locus T, and REVOLUTA. Likewise, about 16 and 12 transcription factors involved in regulating rhizome development and secondary metabolic pathways in rhizomes such as MADS-box, AP2-EREBP, bHLH, MYB, NAC, and WRKY were also found in G. superba and C. autumnale, respectively. Conclusion The predicted genes in $\mathrm{G}$. superba and $\mathrm{C}$. autumnale encode colchicine pathway enzymes that provide fundamental information for plant-based biomedicine engineering in biorhizomes and microorganisms, a potentially important area of synthetic biotechnology. Additionally, increasing our understanding of rhizome functional genomics will lead to improved colchicine biomanufacturing, and generate important knowledge that can be applied to many other medicinal plant species, allowing for the engineered production of additional biomedicines in medicinal rhizomes.

\section{Background}

The growing need for ultrapure plant-based medicines to treat human disease often cannot be met due to a lack of feasible upstream biomanufacturing processes. For example, therapeutic colchicine alkaloid, a drug used to treat cancer, cardiovascular disease, and gout [1-25], is uniquely biosynthesized by the Colchicaceae family and extracted commercially from Gloriosa superba and Colchicum autumnale, important rhizome crops and the prime pharmaceutical source of colchicine. Further, colchicine is an FDA approved drug [26]. The colchicine analog $\mathrm{CH}-35$ was more effective at inhibiting the Blll isotype of breast cancer than taxol [27-30]. The results of clinical trials suggest that colchicine could prevent the recurrence of atrial fibrillation after cardiac surgery and renal diseases [31-34]. Moreover, colchicine is undergoing clinical trials to treat non-diabetic metabolic syndrome and diabetic nephropathy [35-37]. The best 
chemical synthesis method available generates only a $9.2 \%$ yield of $>99 \%(-)$-colchicine [38-39]. On the other hand, plant-based colchicine from G. superba yields approximately $1 \% \operatorname{DW}[22,40]$. However, the annual production of pharmaceutical colchicine is limited by its source [41-45].

Despite the availability of sequence data for the $G$. superba and $C$. autumnale transcriptomes (from the Medicinal Plant Transcriptome https://medplantrnaseq.org/) and their chloroplast genomes, little is known about the colchicine biosynthetic pathway and its regulation in the plant [46]. The efficiency of colchicine biosynthesis likely depends on the interaction of gene circuit elements with other components within the biosynthetic network and how those gene circuits are regulated. This situation with colchicine production is not unusual-as more plant-based medicinally important compounds are discovered, especially where high purity and large amounts are required. To overcome the plant-based therapeutic colchicine production limitation, an advanced non-dormant in vitro biorhizome technology from $G$. superba has been established [47]. Biorhizomes are non-transgenic cultures that produce important biomedicine, which also serves as asexual reproductive organs, and are an advanced biotechnological platform compared to root and cell cultures due to their continuous and rapid colchicine production [48]. Nevertheless, the biochemical pathways and regulatory networks in the biorhizomes that control colchicine biosynthesis are yet to be characterized, leaving a significant barrier to improving colchicine biomanufacturing. Therefore, the first steps in building a synthetic biology toolbox for colchicine production include analysis of genes from the different Colchicaceae species in order to identify regulatory steps and factors that can then be adjusted to enhance colchicine biomanufacturing in the biorhizomes.

The current understanding of colchicine biosynthesis in planta is based on radiolabeling studies [49-51] and the transformation of $O$-methylandrocymbine to demecolcine by microsomes prepared from immature $C$. autumnale seeds [52]. The phenylalanine precursor in the phenylpropanoid pathway and trihydroxylated phenethylisoquinoline in the colchicine pathway have been studied [53-56]. However, research has not been performed at the molecular level to uncover enzymes and regulatory proteins in the colchicine biosynthetic pathway in G. superba or $C$. autumnale. To fully understand how colchicine is biosynthesized in Gloriosa biorhizomes, the key genes and enzymes that control the colchicine pathway from the alkaloidal precursor trihydroxylated phenethylisoquinoline to colchicine must be identified. To this end, we constructed a full-length cDNA library using mRNA isolated from $G$. superba leaves that consists of 2,790 processed sequences, of which 1,379 were assembled into 292 contigs and 1,411 singletons [47]. The cDNA library contains gene families expected to be involved in the colchicine pathway, including NMT, 3-OMT, cytochrome P450s: CYP96T1, CYP82E10, and NAT.Furthermore, we manually curated these gene families and identified specific genes whose corresponding enzymes are excellent candidates for involvement in the colchicine pathway, from the alkaloid formation steps to later steps in the pathway (Figure 1), including: 1) an NMT enzyme that catalyzes the conversion of the trihydroxylated phenethylisoquinoline intermediate to (S)-autumnaline; 2) a P450: CYP96T1 that catalyzes (S)-autumnaline to isoandrocymbine; 3 ) an OMT enzyme that catalyzes the transformation of isoandrocymbine to 3-O-methylandrocymbine; 4 ) a P450 that catalyzes $O$-methylandrocymbine to demecolcine; 5) an additional P450CYP82E10 that catalyzes the conversion of demecolcine to 
deacetylcolchicine; and 6) a NAT enzyme that catalyzes the transfer of an acetyl group from acetyl-CoA to a deacetylcolchicine nitrogen group to yield colchicine [47].

Although significant progress has been made in understanding rhizome-specific functions in plants, the mechanisms underlying the regulation of Gloriosa biorhizome growth, and the dormancy of field-grown $G$. superba and $C$. autumnale are not yet known [57-59]. Similar to many other rhizomatous species, natural $G$. superba and $C$. autumnale rhizomes undergo a dormancy period in their normal growth cycle, but the biorhizomes do not go dormant. Extensive studies examined the phenotypic variation between plant species, but why dormancy-free biorhizomes from different Gloriosa species produce different levels of colchicine in the controlled bioreactor environment remains unclear. The function of dormancyassociated genes (such as specific transcription factors) in biorhizomes and the core regulatory machinery that controls differential colchicine biosynthesis between species are not known. We hypothesize that $G$. superba and $C$. autumnale genes and gene networks are comparable, but that subtle differences in their regulation lead to changes in colchicine accumulation between the species. Comparison of the transcriptomes of these species will aid in filling the identified knowledge gaps.

\section{Results}

Benchmarking universal single-copy orthologue (BUSCO) analysis: Three in vivo tissues (leaf, fruit, and rhizome) were previously used to generate a combined RNA-seq dataset of $G$. superba and $C$. autumnale (https://medplantrnaseq.org/). This investigation of the dataset indicated that the N50 for the assembly was fairly long at 2,134 , given that contigs of $\geq 100$ (instead of $\geq 200$ ) were included in the assembly and that the data were generated from $50 \mathrm{bp}$ single-end reads. The average contig length was somewhat short, however, as the statistic was skewed due to the inclusion of several contigs that were shorter than 200. BUSCO analysis, which in this case examined the core eukaryotic genes in plants, indicated that the dataset was $~ 89 \%$ complete ( $64 \%$ of the genes detected were found as a single sequence in the assembly, and $25 \%$ had duplicated sequences). In comparison, a total transcriptome analysis that we conducted in a different sepcies and that focused on only a single sample type (containing combined RNA samples from the $1^{\text {st }}$ and $2^{\text {nd }}$ Asian Citrus Psyllid instars, including six biological replicates and utilizing 150 bp reads), led to BUSCO analysis results suggesting that the dataset was $96 \%$ complete ( $13 \%$ single sequence and $83 \%$ duplicate sequences), with only $1.4 \%$ fragments of core genes and $2.6 \%$ missing core genes. Thus, although the sequence data used in this analysis were of high quality, it is likely that some important genes may nevertheless still be missing from the dataset.

Annotation and comparative transcriptomes analysis: The $C$. autumnale and $G$. superba transcriptomes consist of 60,927 and 32,312 assembled multiple-tissue transcripts with 21,948 and 15,089 unigenes, respectively, identified as having functions belonging to known plant-specific gene ontology (GO) terms. Among these, 23,247 and 45,292 sequences were assigned and annotated as biological processes, 27,199 and 52,366 sequences as cellular components, and 22,760 and 44,942 sequences as molecular functions in $G$. superba and $C$. autumnale, respectively (Figure 2). The $G$. superba leaf tissue cDNA library was also annotated using the Blast2GO suite and contained a total of 1,703 unigenes with 588 
sequences were assigned to biological process, 700 sequences to cellular component, and 568 sequences to molecular function categories (Figure 2). Figure 3 shows the percentages of GO terms assigned to the transcriptomes of $G$. superba and $C$. autumnale, and the CDNA library. Additional GO terms were used to identify Kyoto Encyclopedia of Genes and Genomes (KEGG) pathway members, putative colchicine pathway enzymes, and rhizome developmental genes, along with transcription factors. KEGG annotated 15184 of 57580 (26.4\%) and 33505 of 100528 (33.3\%) sequences in G. superba and $C$. autumnale transcriptomes, respectively (Figure 4), suggesting that many of the transcripts belong to non-canonical pathways (e.g., are not involved in known signaling pathways or biosynthetic pathways). Many of these reads were characterized as "unknown", as is still typical in transcriptomic analysis of non-model plant species [60-61]. G. superba cDNA library was also annotated by BlastKOALA, which annotated 66 of $848(7.8 \%)$ sequences sets of proteins based on their role in specific pathways (Figure 4).

The mining of $G$. superba and $C$. autumnale transcriptomes revealed a total of 1299 genes that were possible initial candidates for involvement in the colchicine pathway, which included 647 sequences from G. superba and 652 from $C$. autumnale. From 647 candidate sequences in $G$. superba, 186 coded for NMTs, 105 for OMTs, 19 for NATs, and 337 for P450s; while from 652 candidate sequences in $C$. autumnale, 16 were putative NMTs, 106 OMTs, 20 NATs, and 510 P450s (Figure 5). Further, these transcripts were narrowed down to candidates for the genes that catalyze the reactions in the colchicine biosynthetic pathway. Moreover, a total of 339 putative rhizome developmental genes identified based on comparison to known rhizome developmental genes (119 sequences) from Nelumbo nucifera and tuber developmental genes (142 sequences) from Solanum tuberosum such as GI, CO, PHYB, SUSY, FT, and REV were also identified in $G$. superba and $C$. autumnale transcriptomes (Figure 6). Notably, 113 sequences from $G$. superba and226 from $C$. autumnale. In addition, a total of 1146 transcription factor sequences associated with rhizome development namely MADS-box, AP2-EREBP, bHLH, MYB, NAC, and WRKY were analyzed (Figure 7). This included 481 sequences from G. superba and 665 from C. autumnale.

Phylogenetic trees of colchicine pathway, rhizome development, and transcription factors (with a total of 65,58 , and 59, respectively) of full-length amino-acid candidate and reference genes were constructed using the PHYLIP-3.697 software with the objective to examine the genetic divergence between two colchicine producing plants, G. superba and $C$. autumnale, and their reference sequences.

\section{Discussion}

What genes are expressed in rhizomes? Several recent investigations have identified rhizome-specific genes in different rhizomatous plants by directly comparing leaves, other tissues, and rhizomes, leading to the detection of genetic mechanisms responsible for controlling rhizome development, growth, and metabolism. Many genes exhibit significantly altered expression during rhizome development but genes associated with auxin hormone signaling appear to trigger rhizome induction [57-59]. The rhizome developmental gene REV is highly expressed in bamboo rhizome buds and plays an important role in meristem initiation [62]. In potato plants, calmodulin-binding protein plays a regulatory role in signal transduction for tuber formation [63]. In addition, the $F T, C O$, and $G /$ genes are involved in the 
transduction of photoperiodic signals, which may promote rhizome budding in potatoes [64-65]. Tubers are not rhizomes, but there are some similarities to their growth that may include involvement of analogous genes. There are 14 other important rhizome formation-related genes, including a MADS-box that could be involved in rhizome enlargement [66]. Genes encoding PHYB, CO, GI, FT and SuSy were identified in Lotus rhizomes, but their expression and regulation differed in the shoot and rhizome [60]. Transcription factor families such as AP2-EREBP, bHLH, MYB, NAC, and WRKY were reported to be important in regulating specialized metabolic pathways in rhizomes [61]. Bioactive small molecules such as curcuminoid and candidate genes for gingerol synthesis are also highly expressed in rhizomes [67-71]. Notably, biosynthetic genes involved in benzylisoquinoline alkaloid formation were highly upregulated during bulb development in Corydalis yanhusuo [72]. In wild rice, microRNAs were differentially expressed in aerial shoots and rhizomes [73]. However, the exact roles that the corresponding genes might play in biorhizomes are not known. This information provides a framework for our analysis of biorhizomeexpressed genes and the identification of specific genes involved in biorhizome growth, resistance to dormancy and production of colchicine in this interesting biotechnology platform.

Why are colchicine pathway candidate NMT, P450s (CYP96T1 and CYP82E10), 3-OMT, and NAT genes from the transcriptomes the best targets? First, a cDNA contig consisting of three sequences showed significant sequence similarity to Ricinus communis NAT and partial similarity to an analogous gene from Oryza sativa. This contig, which contains a full-length transcript (cDNA Gloriosa 148), is a potential candidate for encoding the enzyme that catalyzes the acetyl transfer from acetyl-CoA to deacetylcolchicine to form colchicine, the final step in the proposed colchicine pathway [52]. The putative NAT gene also showed $100 \%$ homology to a full-length transcript in the G. superba transcriptome (Gloriosa-20120814|26859). Similarly, two NAT catalyzed reactions were identified in melatonin biosynthesis in 0 . sativa[74-75], carried out by SNAT1 and SNAT2 enzymes. The SNAT1 transcript Q5KQI6.1 is a possible alternative reference sequence, with an identity of $69 \%$, and $77 \%$, respectively, to transcripts in the G. superba and C. autumnale transcriptomes (Gloriosa-20120814|70209_1 and Colchicum_20101112|6813; see Table 1 and Figure 8).

Second, the cDNA clone (Gloriosa 14D06) identified as encoding a putative NMT is a partial clone consisting mainly of the $3^{\prime}$ end of the CDNA (Table 1 and Figure 8). The putative NMT clone had high sequence homology to a Coptis japonica NMT, which catalyzes a similar $\mathrm{N}$-methylation reaction involved in (S) - $N$-methylcoclaurine formation in the benzylisoquinoline pathway and has a near identical fulllength transcript in the G. superba transcriptome (Gloriosa-20120814_33123). The putative NMT is a one candidate for the $\mathrm{N}$-methylation step that converts the trihydroxylated phenethylisoquinoline intermediate to $(S)$ autumnaline, the first alkaloidal precursor formation step in the proposed colchicine pathway [52, 76]. Other candidates include, the G. superba putative NMT transcript Gloriosa-20120814|64082_1, which was found to be $58 \%$ identical to $C$. japonica coclaurine NMT (BAB74802.1), and Colchicum_20101112|85, a transcript with 48.7\% identity to pavine NMT (PNMT, sp|C3SBW0.1) from Thalictrum flavum (PNMT) converts ( $S$ )-tetrahydropapaverine to $(S)$-laudanosine in the benzylisoquinoline alkaloid pathway that is common in many plants [77]. PNMT is also considered a possible alternative reference sequence due to its capability of adding a methyl group to (S)- 
tetrahydropapaverine where the nitrogen is present, which is similar to the colchicine pathway mechanism. These putative transcripts also share homology with reticuline NMT involved in biosynthesis of the aporphine alkaloid magnoflorine in opium poppy roots [78].

Third, the cDNA clone (Gloriosa 8E03) identified as a putative P450 is a partial clone with $87 \%$ sequence homology to Narcissus pseudonarcissus CYP96T1, which catalyzes a C-C phenol coupling reaction in noroxomaritidine biosynthesis in the haemanthamine pathway and has an identical full-length transcript in the $C$. autumnale transcriptome (Colchicum-20101112_3005). This putative enzyme might be a candidate for the para-para phenol-tropolone oxidative coupling bridge-forming P450 CYP96T1, that is $\mathrm{NADPH}$ and $\mathrm{O}_{2}$-dependent and converts (S)-autumnaline to isoandrocymbine [79-80]. In Papaver somniferum, salutaridine synthase enzyme (CYP719B1)is responsible for the C-C phenol coupling converting $(R)$-reticuline to salutaridine by connecting the 12 and 13 carbon [81-82]. P. somniferum CYP719B1 enzyme could also be considered as an alternative reference gene because of its C-C phenolcoupling mechanisms in the morphine pathway. Furthermore, in C. japonica, CYP80G2 has been shown to convert $(S)$-reticuline to $(S)$-corytuberine through $\mathrm{C}-\mathrm{C}$ phenol-coupling in an isoquinoline alkaloid pathway [83]. The G. superba and $C$. autumnale transcriptomes contained transcripts (Gloriosa20120814|30999_1 and Colchicum_20101112|76071) that shared of 52.7\% and 51.7\% identity, respectively, with CYP80G2 (sp|A8CDR5.1; see Table 1 and Figure 8).

Fourth, the cDNA clone (Gloriosa 7D05) identified as a putative OMTis a partial clone with high sequence homology to Narcissus sp. aff. pseudonarcissus norbelladine-4-OMT, which participates in a similar $O$ methylation reaction to form $O$-methylnorbelladine in the galanthamine pathway and has an identical full-length transcript in the G. superba transcriptome (Gloriosa-20120814_6585 and Gloriosa20120814|82787_1). This putative OMT is a likely candidate for the proposed 3-O-methylation step that would catalyze the conversion of isoandrocymbine to 0 -methylandrocymbine [84]. The 3-OMT is expected to be a class I methyltransferase, similar to other members of this gene family that are involved in plant alkaloid metabolism. Additional reference 3-OMT sequences, such as AFB74613.1 from $P$. somniferum and sp|A0A077EWA5.1 | from N. pseudonarcissus, were considered when filtering G. superba and $C$. autumnale transcriptomes for possible alternative 3-OMTs Gloriosa-20120814|16875_1 and Gloriosa-20120814|82787_1 were found to possess 50.9\% and $72.8 \%$ identity, respectively, to the sequences. The transcript Colchicum_20101112|23611 showed an identity of 58.1\% to the $N$. pseudonarcissus gene (Table 1 and Figure 9). In P. somniferum 3-OMT catalyzes the conversion of 4' $-O$ desmethyl-3-O-acetylpapaveroxine to 3-O-acetylpapaveroxine by forming a heterodimer with $2-0 \mathrm{MT}$ in the noscapine pathway [85-86].

Fifth, the cDNA clone (Gloriosa 1F02) identified as another putative P450 is a partial clone with 79\% sequence homology to CYP82E10 from Fragaria $x$ ananassa and Nicotiana tabacum, which catalyzes an $\mathrm{N}$-demethylation reaction from nicotine to nornicotine and has a full-length homolog in the $C$. autumnale transcriptome (Colchicum-20101112_5364). This putative P450 enzyme might be a candidate for the $N$ demethylation that converts demecolcine to deacetylcolchicine [87]. Nevertheless, in N. tabacum three cytochrome P450 superfamily of monooxygenases that catalyze the $\mathrm{N}$-demethylation of nicotine have 
been identified, CYP82E4, CYP82E5v2, and CYP82E10[88]. CYP82E4 is the major nicotine demethylase enzyme responsible for converting nicotine to nornicotine [89]. The demethylase P450 enzymes CYP82E5v2and CYP82E10 were expressed in nonsenescent green leaves and/or root tissue in $N$. tabacum [87, 89-93]. The transcripts, Gloriosa-20120814|5091 and Colchicum_20101112|74349 were found to possess $53.4 \%$, and 54\% identity, respectively, to NP_001312976.1 (CYP82E4; see Table 1 and Figure 9). Thus, enzymes belonging to the predicated NMT, 3-OMT, CYP96T1, CYP82E10, and NAT families are likely to be early targets for cloning and characterization in the colchicine pathway. However, the possibility exists that one or more of the candidate genes will not function as predicted. In this case, other genes from the $G$. superba and $C$. autumnale transcriptomes that show homology to colchicine pathway enzymes would also be considered as candidate genes.

\section{What genes are candidate rhizome developmental genes from G. superba and C. autumnale?} Underground rhizome (storage organ) development and the molecular mechanisms controlling rhizome enlargement and dynamics remain unclear, even in well-studied medicinal and invasive plants [60, 68-69]. Biorhizomes can be a suitable system to study rhizome growth and biomedicine biomanufacturing because they are much more accessible than plant tissues growing in the soil. In addition, it is useful to identify genes related to rhizome development as they likely control key resources involved in biomass yield. Several genes have been identified from other species that affect rhizome formation in different rhizomatous crops, but comparable genes have not been characterized in the Colchicaceae. Therefore, characterizing rhizome developmental genes from $G$. superba and $C$. autumnale could allow clarification of molecular intricacies involved in biorhizome biomass production and lead to enhanced biomanufacturing. To screen for rhizome developmental genes in colchicine producing species, the transcriptomes from $G$. superba and $C$. autumnale were analyzed as described above for metabolism related genes. Specific results related to major development-related genes are outlined below.

$G /$ is a sensor gene that involved in seasonal growth, which includes tuber development in potato [61, 9496]. The reference $\mathrm{G} /$ sequence from N. nucifera transcriptome (gi|720040388|ref|XP_010268589.1|) and S. tuberosum transcriptome (PGSC0003DMT4000048370) were compared with $G$. superba and $C$. autumnale transcriptomes. Two potential full-length candidate genes Gloriosa-20120814|8521_1 and Gloriosa-20120814|11998_1 1 shared an identity of 70\%, and 76\%, respectively, to these genes (Table 2 and Figure 9).

$\mathrm{CO}$ genes play an important role in the circadian clock and rhizome development in radish and potato [9798]. Five full-length sequences reveled CO functionality in Gloriosa-20120814|18001_1, Gloriosa20120814|51159_1, Gloriosa-20120814|17037_1, Gloriosa-20120814|20079_1, and Gloriosa20120814|72100_1. The reference sequence from S. tuberosum (NP_001274795.1) shared an identity with candidate sequences of 64\%-73\%. While Colchicum_20101112|3159, Colchicum_20101112|5391, Colchicum_20101112|26221, and Colchicum_20101112|27602 shared an identity of $72 \%-82 \%$. The alternate reference sequence from $S$. tuberosum (PGSC0003DMT 400067656) shared an identity with candidate sequences Gloriosa-20120814|51159_1 of 76\% and Colchicum_20101112|3159 of 82\%. The reference sequence from N. nucifera (gi|719967386|ref|XP_010261698.1|) shared an identity with 
candidate sequences Gloriosa-20120814|51159_1 of 84\% and Colchicum_20101112|3159 of 82\% (Table 2 and Figure 9).

$F T$ and $F T$-like protein StSP6A are key components of tuberigen and a systemic floral inducer in potato [99]. By employing computational analysis using RNA-Seq data, we identified five full-length $F T$ candidate genes such as Gloriosa-20120814|55554_1, Gloriosa-20120814|55004_1, Gloriosa-20120814|26010_1, Gloriosa-20120814|45011_1, and Gloriosa-20120814|52745_1), while two candidate genes from Colchicum_20101112|8829 and Colchicum_20101112|22914. The FT reference sequence from S. tuberosum (StSP6A NP_001274897.1) shared an identity range with candidate genes of $60 \%-74 \%$. The alternative $F T$ reference sequence from S. tuberosum (PGSC0003DMT400060057) shared an identity with candidate sequence Gloriosa-20120814|55554_1 of 76\% and two sequences with Colchicum_20101112|8829 and Colchicum_20101112|22914 of 75\% and 79\%, respectively. The FT reference sequence from N. nucifera (gi|720039388|ref|XP_010268289.1|) shared an identity with Gloriosa-20120814|55554_1 of 84\% and two candidate genes with Colchicum_20101112|8829 and Colchicum_20101112|22914 of $81 \%$ and $86 \%$, respectively (Table 2 and Figure 9).

The photoreceptor $P H Y B$ is involved tuber induction and microRNA, miR172 highly expressed in potato tuber [100]. It has been shown in N. nucifera that $P H Y B$ and/or other phytochromes might measure the length of the light period to affect rhizome girth enlargement [61]. The PHYB candidate gene Gloriosa20120814|36050_1 and Colchicum_20101112|1221 shared an identity of 81\% with the reference sequence from N. nucifera (gi|720038316|ref|XP_010267948.1|). The PHYB reference sequence from S. tuberosum (PGSC0003DMT400061712) shared an identity of $81 \%$ with candidate sequence Gloriosa20120814|85746_1) and 80\% with Colchicum_20101112|1221 (Table 2 and Figure 9).

SuSy plays a key role in tubers biomass allocation, starch biosynthesis and storage, and cleaves sucrose into fructose and UDP-glucose [101-102]. Two full-length SuSy sequences were identified in G. superba such as Gloriosa-20120814|9073_1 and Gloriosa-20120814|69933_1); whereas five candidate genes in C. autumnale Colchicum_20101112|583, Colchicum_20101112|593, Colchicum_20101112|2693, Colchicum_20101112|13826, and Colchicum_20101112|33099, which shared an identity of 81-82\% with N. nucifera (gi|720050864|ref|XP_010271909.1|). The reference sequence from S. tuberosum (PGSC0003DMT400007506) shared an identity of $78 \%$ with candidate sequence Colchicum_20101112|2693 (Table 2 and Figure 9).

$R E V$ plays an important role during morphogenesis and controlling the apical meristem formation during rhizome development in bamboo $[61,103]$. Since, biorhizomes are compressed scale leaves that replicate rhizomes possessing vegetative buds [47], at the molecular level an intricate regulatory network determines initial biorhizome development and $R E V$ could antagonistically regulate lamina structures that trigger formation of specialized organs. The REV reference sequence from $N$. nucifera (gi|720097995|ref|XP_010247499.1|) shared an identity with candidate Gloriosa-20120814|11056_1 sequence of $86 \%$ and Colchicum_20101112|467 of 85\%. The reference sequence from S. tuberosum (PGSC0003DMT400030829) shared an identity with Gloriosa-20120814|17486_1 of 81\% and 
Colchicum_20101112|467 of 81\%. Additionally, the REV-like homolog (PpHB1) was found in bamboo, which highly expressed in the tips of lateral buds at several developmental stages [104]. BLAST analysis of Gloriosa-20120814|15982_1 and Colchicum_20101112|6503 showed a 79\% and 78\% identity when compared to $P p H B 1$, respectively (Table 2 and Figure 9 ).

What are the transcription factors in G. superba and $C$. autumnale? Currently, no information is known about transcription factors in $G$. superba and $C$. autumnale. Besides rhizome developmental genes, an important subset of rhizome transcription factors genes was also identified. It was suggested that MADSbox (containing the MADS domain), AP2-EREBP (APETALA2/ethylene-responsive element binding protein), bHLH (basic helix-loop-helix), MYB (myeloblastosis related), NAC (no apical meristem), and WRKY (contain the highly conserved amino acid sequence WRKYGQK and the zinc-finger-like motifs Cys(2)-His(2) or Cys(2)-HisCys, and bind to the TTGAC(C/T) W-box cis-element in the promoter of their target genes) proteins can act as rhizome developmental transcription factors [105-108]. Several genomewide analyses have been conducted on these transcription factors in S. tuberosum, N. nucifera and Sinopodophyllum hexandrum $[61,105,109]$. The screened candidate transcription factors listed below could contribute to our understanding of the molecular mechanism of biorhizome development. Moreover, a better understanding of the regulation of colchicine production will be gained by identifying how candidate colchicine biosynthetic gene family members interact with and are controlled by rhizome developmental genes and transcription factors in G. superba and C. autumnale.

MADS-box genes were present on all 12 potato chromosomes, and StMADS1 and StMADS13 were proposed to be likely downstream targets of StSP6A and involved in tuber development [105]. Therefore, the known S. tuberosum and N. nucifera MADS-box sequences were used as query to perform BLAST against the $G$. superba and $C$. autumnale protein databases. One full-length candidate sequence Gloriosa$20120814 \mid 19828$ 1 shared an identity of $77 \%$ with an N. nucifera gene (gi|720053055|ref|XP_010272608.1|). The reference sequence from S. tuberosum (PGSC0003DMT400000026) shared an identity of 81 and $82 \%$ with candidate sequences Colchicum_20101112|22985 and Gloriosa-20120814|35037_1, respectively (Table 3 and Figure 9).

AP2 (APETALA2) and EREBPs are some of the largest and the prototypic families of transcription factors unique to plants and are upregulated in rhizomes [110-111]. Four AP2-EREBP candidate genes were Gloriosa-20120814|77954_1, Gloriosa-20120814|7267_1, Gloriosa-20120814|54352_1, and Gloriosa20120814|45526_1 based on homology to the reference sequences in N. nucifera (gi|720011136|ref|XP_010259468.1|) with identities of $66 \%, 69 \%, 82 \%$, and $86 \%$, respectively. In addition, full-length alternative sequences were identified using a reference sequence from $S$. tuberosum (PGSC0003DMT400016585) such as Colchicum_20101112|4936 and Colchicum_20101112|10921 from C. autumnale with identities of $76 \%$ and $82 \%$, respectively. Of the six AP2-EREBP candidate genes, two (Gloriosa-20120814|7267_1 and Gloriosa-20120814|77954_1) were found to be $100 \%$ identical to $G$. superba leaf tissue cDNA Gloriosa 8E03 (Table 3 and Figure 9). 
The bHLH superfamily of proteins is the second largest transcription factor family in plants and StbHLH76 and StbHLH86 had relatively high expression levels in the potato tuber compared to other tissues [112]. The full-length sequence of Gloriosa-20120814|6279_1 demonstrated possible bHLH functionality with a reference sequence from $N$. nucifera (gi|720006121|ref|XP_010257880.1|) with an identity of $90 \%$. The reference sequence from S. tuberosum (PGSC0003DMT400022702) shared an identity of $89 \%$ with the $b H L H$ candidate sequence Gloriosa-20120814|53746_1). Additionally, the reference sequence from N. nucifera (gi|719971259|ref|XP_010273628.1|) shared an identity of 82\% with the $b H L H$ candidate sequence from $C$. autumnale Colchicum_20101112|7042. Likewise, S. tuberosum (PGSC0003DMT400022701) shared an identity of $86 \%$ with the candidate sequence Colchicum_20101112|21881 (Table 3 and Figure 9)

The MYB transcription factors are consider potentially important regulators of secondary metabolism, where the R2R3-MYB proteins are specific to plants [113-115]. The reference R2R3-MYB sequence from N. nucifera (gi|719972251|ref|XP_010277005.1|) shared an identity of $91 \%$ with the MYB candidate sequence (Gloriosa-20120814|15461_1). The reference sequence from S. tuberosum (PGSC0003DMT400012203) shared and identity of $91 \%$ with the MYB candidate sequence Gloriosa20120814|15461_1. In C. autumnale, candidate sequence Colchicum_20101112|11314 shared an identity of $87 \%$ with $N$. nucifera (gi|719993192|ref|XP_010253806.1|). Likewise, the S. tuberosum sequence(PGSC0003DMT400017709) shared an identity of $86 \%$ with candidate sequence Colchicum_20101112|20668 (Table 3 and Figure 9).

There is abundant evidence indicating that NAC proteins play crucial roles in hormone signaling, lateral root development and are upregulated during rhizome formation [61, 116-117]. NAC candidate sequence Gloriosa-20120814|28710_1 shows 84\% identity with reference gene from N. nucifera (gi|720085419|ref|XP_010243512.1|). An alternative gene Gloriosa-20120814|18396_1, was 81\% identical to $S$. tuberosum PGSC0003DMT400045294. The reference sequence from N. nucifera (gi|720046186|ref|XP_010270427.1|) shared an identity of 71\% with candidate sequence Colchicum_20101112|44481 and S. tuberosum (PGSC0003DMT400079789) shared an identity $71 \%$ with Colchicum_20101112|794 (Table 3 and Figure 9).

WRKY proteins can regulate diverse responses in rhizome-related gene networks, including sprouting mechanisms in potato tuber and in specialized metabolism [118-119]. Two full-length candidate sequences, Colchicum_20101112|3957 and Colchicum_20101112|49701, shared significant homology with the reference sequence from Sinopodophyllum hexandrum (ALD83482.1), with 76\% and 80\% identity, respectively. A similar sequence from Gloriosa-20120814|20138_1 shared an identity of $72 \%$. The reference sequence from N. nucifera (gi|720006863|ref|XP_010258120.1|) shared an identity of 77\% with Gloriosa-20120814|20164_1. The reference sequence from S. tuberosum (PGSC0003DMT400028529) shared an identity of $77 \%$ with candidate sequence Gloriosa-20120814|66904_1. The alternative reference sequence from $N$. nucifera (gi|720007162|ref|XP_010258216.1|) shared an identity of 81\% with candidate sequence Colchicum_20101112|22998 and S. tuberosum (PGSC0003DMT400072835) shared and identity percentage with Colchicum_20101112|22998_ of 81\% (Table 3 and Figure 9). 
Phylogenetic analysis of colchicine pathway, rhizome developmental, and transcription factor protein in G. superba and $C$. autumnale: A total of 20 and 29 candidate colchicine pathway enzymes in $G$. superba and $C$. autumnale transcriptomes, respectively, were split into four primary clusters and mapped against 4 cDNA and 12 reference enzymes (Table 1 and Figure 10A). Among these, step 1 NMT contained 7 genes in the clade such as 3 from $G$. superba transcriptome, 1 from $G$. superba cDNA, and 1 from $C$. autumnale transcriptome. Both step 2 and step 4 P450s genes were closely related and aligned in the same clade but step 2 P450 genes was nested within step 4. Within the step 2 P450's nest, 2 genes in G. superba and5 in $C$. autumnale transcriptomes and 1 cDNA. While in step 4, 1 in $G$. superba and 4 in $C$. autumanle transcriptomes and 1 in CDNA, which indicates that the P450 genes could be evolutionarily similar. The largest clade represented by OMT, which encompassed $15 \mathrm{G}$. superba and $10 \mathrm{C}$. autumnale genes. The last cluster NAT was comprised of 4 genes in $G$. superba and 3 in $C$. autumnale transcriptomes and 1 in cDNA.

Additionally, rhizome developmental gene identification of potential orthologous between G. superba and C. autumnale is one of the most important bottlenecks in transcriptomics [120]. Notably, rhizome developmental genes such as $G I, C O, F T, P H Y B$, SUSy, and REV have been mapped in $G$. superba and $C$. autumnale transcriptomes using reference genes from $S$. tuberosum, N. nucifera, $A$. thaliana, and $P$. praecox. A total of $19 \mathrm{G}$. superba and $15 \mathrm{C}$. autumnale candidate genes were mapped against 24 reference genes to identify possible rhizome developmental unigenes (Figure 10B). Furthermore, rhizome developmental phylogenetic analysis shows 6 distinct clusters, among them $C O$ represents the largest clade. In addition, the transcription factor plays a crucial role in rhizome development [121]. A total of 16 and 12 transcription factors were mapped in the $G$. superba and $C$. autumnale transcriptomes, respectively (Figure 10C). To better reveal the genes associated with rhizome development, 6 transcription factor families were analyzed such as MADS-box, AP2-EREBP, bHLH, MYB, NAC, and WRKY that showed good correlation between the clusters of protein families. The mapped rhizome developmental gene families explains the conserved sequence homology between reference and candidate genes, which indicates a network of genetic mechanisms in $G$. superba and $C$. autumnale are crucial for rhizome development.

Interestingly, the phylogenetic trees of colchicine pathway, rhizome developmental, and transcription factors indicate that the candidate genes of $G$. superba and $C$. autumnale were common to Colchicaceae due to high homology and evolution similarity of the candidate genes. This suggests that the predicted candidate genes not only are involved in colchicine biosynthesis in rhizomes but are also involved in the rhizome metabolism. In comparison with tuber producing S. tuberosum and N. nucifera, rhizome developmental and transcription factor genes from $G$. superba and $C$. autumnale showed nearly the same transcriptional regulation map that are possible downstream targets of rhizome initiation or biomass production. The annotated genes from $G$. superba and $C$. autumnale can contributes to identifying candidate genes in the biosynthesis of different groups of secondary metabolites in biorhizome and rhizome developmental genes, which could serve as a comprehensive resource for molecular mechanism research of colchicine biosynthesis in G. superba. This provides a molecular platform and resource for future genetic and functional rhizomatous medicinal crops genomic research. 


\section{Conclusions}

In this study, we have interrogated two evolutionarily diverse transcriptomes of $G$. superba and $C$. autumnale to predict genes that encode candidate proteins of colchicine biosynthesis and rhizome metabolism. G. superba and $C$. autumnale are rhizomatous medicinal plants that lack reference genomes. Collectively, transcriptomes and cDNA approaches were applied to select candidate genes for each predicted colchicine pathway step, which should help to elucidate the colchicine biosynthetic pathway. Additionally, our work will be useful to identifying rhizome developmental genes and transcription factors in $G$. superba and $C$. autumnale, with the ultimate goal of improving biorhizome biomass. The predicted genes in this work now need to be functionally validated, and are an important resource for metabolic engineering or synthetic biotechnology that could improve colchicine biomanufacturing.

\section{Methods}

cDNA library

A full-length cDNA library was constructed from a month-old $G$. superba biorhizome derived leaves. Total RNA isolation and cDNA library construction were performed according to previous protocols [122]. The assembled cDNA sequences were BLASTed against the National Center for Biotechnology Information (NCBI) database (http://www.ncbi.nlm.nih.gov/), and G. superba and C. autumnale transcriptomes.

Prediction of colchicine pathway and rhizome developmental proteins

The G. superba and $C$. autumnale transcriptomes were obtained from our Medicinal Plant Transcriptome database (https://medplantrnaseq.org/). BUSCO analysis of transcriptomes were processed according to Waterhouse et al. [123]. Colchicine pathway and rhizome developmental along with its transcription factors encoding proteins were predicted from the NCBI database.

Functional annotation of transcriptomes, colchicine pathway and rhizome developmental proteins

The $G$. superba and $C$. autumnale transcriptomes $\mathrm{GO}$ classification of the identified know plant proteins was performed using the web-accessible Blast2GO v5 annotation system (https://www.blast2go.com/) [124]. Blast2GO is an all-in-one bioinformatics software for protein functional prediction and the genomewide analysis of annotation data. KEGG pathway enrichment analysis was used to analyze the functional significance of biochemical pathways using BlastKOALA and GhostKOALA. The first step in Blast2GO is to align cDNA nucleotide sequences against the NCBI non-redundant database by Basic Local Alignment Search Tool protein (BLASTp/BLASTn) with an expectation value of $1 \mathrm{e}^{-5}$. Next, transcriptomes FASTA protein sequences were uploaded to Blast2GO for BLAST analysis to identify homologous sequences, then mapping and annotation were performed. The significantly enriched biological processes, molecular function, cellular component and KEGG pathway were identified by $p$ value less than threshold value 0.05. The colchicine pathway candidate genes with their specific enzymatic function and high homology 
were identified using alkaloid metabolic reference genes such as NMT; 3-OMT; two cytochrome P450s: CYP96T1 and CYP82E10; and NAT for comparison [74-89]. Rhizome developmental genes namely GI, CO, $P H Y B$, SUSY, FT and REV as well as transcription factors such as MADS-box, AP2-EREBP, bHLH, MYB, $N A C$, and $W R K Y$, were identified in like manner using reference genes from $S$. tuberosum and $N$. nucifera [https://plants.ensembl.org/Solanum_tuberosum/Info/Index and ftp://ftp.ncbi.nih.gov/genomes/].

Phylogenetic analysis of possible total colchicine pathway, rhizome developmental, and transcription factor proteins

Gloriosa superba and Colchicum autumnale possible candidate colchicine pathway, rhizome developmental, and transcription factor protein sequences were aligned using ClustalW version 2.1. The phylogenetic trees were constructed from the PHYLIP-3.697 package using the Seqboot, Protdist, Neighbor, and Consense programs [125]. For tree visualization, Interactive Tree of Life (iTOL) software was used [https://itol.embl.de/] [105].

\section{Abbreviations}

AP2-EREBPAPETALA2/ethylene-responsive element binding protein

bHLH Basic-Helix-Loop-Helix

BLASTBasic Local Alignment Search Tool

BUSCOBenchmarking universal single-copy orthologue

cDNA Complementary DNA

CO CONSTANS

DW Dry weight

FT Flowering Locus T

GI GIGANTEA

GO Gene Ontology

iTOL Interactive Tree of Life

KEGGKyoto Encyclopedia of Genes and Genomes

MADS Mini chromosome maintenance 1

MYB Myeloblastosis related

NAC No apical meristem 
NAT N-acetyltransferase

NCBI National Center for Biotechnology Information

NMT N-methyltransferase

OMT O-methyltransferase

PHYB Phytochrome B

PHYLIPPHYLogeny Inference Package

qRT-PCRQuantitative Real Time Polymerase Chain Reaction

REV REVOLUTA

SuSy Sucrose Synthase

\section{Declarations}

Ethics approval and consent to participate

Not applicable

Consent for publication

Not applicable

Availability of data and materials

The Gloriosa superba and Colchicum autumnale transcriptomes are available at Medicinal Plant Transcriptome database at https://medplantrnaseq.org/.

Competing interests

The authors declare that they have no competing interests.

Funding

The authors would like to thank National Research University Fund \#110661 from the University of Houston.

Author's contribution

JSM carried out the sequence annotations and bioinformatic analyses. GS provided CDNA and the design of the study as well as wrote the manuscript. TMK established transcriptomes and DG conceived of, 
designed and coordinated the rhizome developmental gene verification. All authors read and approved the final manuscript.

Acknowledgments

We acknowledge Megan M. Augustin for transcriptome establishment.

\section{References}

1. Ozmen N, Kaya-Sezginer E, Bakar-Ates F. The cellular uptake and apoptotic efficiency of colchicine is correlated with down-regulation of MMP-9 mRNA expression in SW480 colon cancer cells. Anticancer Agents Med Chem. 2018, 18: 1927-1933.

2. Blasco V, Cuñat AC, Sanz-Cervera JF, Marco JA, Falomir E, Murga J, Carda M. Arylureas derived from colchicine: Enhancement of colchicine oncogene downregulation activity. Eur J Med Chem. 2018, 150: 817-828.

3. Dybowska M, Szturmowicz M, Kuca P, Kazanecka B, Burakowski J, Czajka C, Grzegorczyk F, Langfort R, Burakowska B, Rudziński P, Tomkowski W. Intrapericardial cisplatin combined with oral colchicine resulted in long term control of malignant pericardial effusion in the course of metastatic renal cancer. Adv Respir Med. 2018, doi: 10.5603/ARM.a2018.0030.

4. Dasgeb B, Kornreich D, McGuinn K, Okon L, Brownell I, Sackett DL. Colchicine: An ancient drug with novel applications. Br J Dermatol. 2018, 178: 350-356.

5. Roitman A, Ben-Zvi I, Mendel L, Livneh A. Inflammation and cardiovascular disease in familial Mediterranean fever. An analysis of hospital admissions for acute cardiovascular event. Clin Exp Rheumatol. 2018, 36: 80-85.

6. Cimmino G, Tarallo R, Conte S, Morello A, Pellegrino G, Loffredo FS, Calì G, De Luca N, Golino P, Trimarco B, Cirillo $\mathrm{P}$. Colchicine reduces platelet aggregation by modulating cytoskeleton rearrangement via inhibition of cofilin and LIM domain kinase 1. Vascul Pharmacol. 2018, 111: 62-70.

7. Vaidya K, Martínez G, Patel S. The role of colchicine in acute coronary syndromes. Clin Ther. 2019, 41: 11-20.

8. Schenone AL, Menon V. Colchicine in pericardial disease: From the underlying biology and clinical benefits to the drug-drug interactions in cardiovascular medicine. Curr Cardiol Rep. 2018, 20: 62.

9. Chaldakov GN. Colchicine, a microtubule-disassembling drug, in the therapy of cardiovascular diseases. Cell Biol Int. 2018, 42: 1079-1084.

10. Arbel Y, Abuzeid W, Rosenson RS, Weisman A, Farkouh ME. Old drugs for new indications in cardiovascular medicine. Cardiovasc Drugs Ther. 2018, 32: 223-232. 
11. Akodad M, Fauconnier J, Lacampagne A, Roubille F. Reply concerning "Colchicine in coronary artery disease: Role of anti-inflammatory medications redefined": Prime time for anti-inflammatory agents for the management of cardiovascular diseases. Int J Cardiol. 2018, 254: 52.

12. Ashish K, Bandyopadhyay D, Mondal S, Ghosh RK. Colchicine in coronary artery disease: Role of antiinflammatory medications redefined. Int J Cardiol. 2018, 254: 51.

13. Liantinioti G, Argyris AA, Protogerou AD, Vlachoyiannopoulos $P$. The role of colchicine in the treatment of autoinflammatory diseases. Curr Pharm Des. 2018, 24: 690-694.

14. Vaidya K, Arnott C, Martínez GJ, Ng B, McCormack S, Sullivan DR, Celermajer DS, Patel S. Colchicine therapy and plaque stabilization in patients with acute coronary syndrome: A CT coronary angiography study. ACC Cardiovasc Imaging, 2018, 11: 305-316.

15. Slobodnick A, Krasnokutsky S, Lehmann RA, Keenan RT, Quach J, Francois F, Pillinger MH. Colorectal cancer among gout patients undergoing colonoscopy. Clin Rheumatol. 2018, doi:

10.1097/RHU.0000000000000893.

16. Pascart T, Richette P. Colchicine in gout: An update. Curr Pharm Des. 2018, 24: 684-689.

17. Slobodnick A, Shah B, Krasnokutsky S, Pillinger MH. Update on colchicine, 2017. Rheumatology (Oxford), 2018, 57: 4-11.

18. Capistrano R, Vangestel C, Wouters A, Dockx Y, Pauwels P, Stroobants S, Apers S, Lardon F, Pieters L, Staelens S. Efficacy screening of Gloriosa superba extracts in a murine pancreatic cancer model using (18)F-FDG PET/CT for monitoring treatment response. Cancer Biother Radiopharm. 2016, 31: 99-109.

19. Capistrano I R, Vangestel C, Vanpachtenbeke H, Fransen E, Staelens S, Apers S, Pieters L. Coadministration of a Gloriosa superba extract improves the in vivo antitumoural activity of gemcitabine in a murine pancreatic tumour model. Phytomedicine, 2016, 23: 1434-1440.

20. Budchart P, Khamwut A, Sinthuvanich C, Ratanapo S, Poovorawan Y, Thienprasert NP. Partially purified Gloriosa superba peptides inhibit colon cancer cell viability by inducing apoptosis through p53 upregulation. Am J Med Sci. 2017, 354: 423-429.

21. Johnson L, Goping IS, Rieger A, Mane JY, Huzil T, Banerjee A, Luduena R, Hassani B, Winter P, Tuszynski JA. Novel colchicine derivatives and their anti-cancer activity. Curr Top Med Chem. 2017, 17: 2538-2558.

22. Sivakumar G. Colchicine semisynthetics: Chemotherapeutics for cancer? Curr Med Chem. 2013, 20: 892-898.

23. Arnst KE, Wang Y, Hwang DJ, Xue Y, Costello T, Hamilton D, Chen Q, Yang J, Park F, Dalton JT, Miller DD, Li W. A potent, metabolically stable tubulin inhibitor targets the colchicine binding site and overcomes 
Taxane resistance. Cancer Res. 2018, 78: 265-277.

24. Worachartcheewan A, Songtawee N, Siriwong S, Prachayasittikul S, Nantasenamat C, Prachayasittikul V. Rational design of colchicine derivatives as anti-HIV agents via QSAR and molecular docking. Med Chem. 2018, doi: 10.2174/1573406414666180924163756.

25. Ghawanmeh AA, Chong KF, Sarkar SM, Bakar MA, Othaman R, Khalid RM. Colchicine prodrugs and codrugs: Chemistry and bioactivities. Eur J Med Chem. 2018, 144: 229-242.

26. Kesselheim AS, Franklin JM, Kim SC. Reductions in use of colchicine after FDA enforcement of market exclusivity in a commercially insured population. J Gen Intern Med. 2015, 30: 1633-1638.

27. Yeh LC, Banerjee A, Prasad V, Tuszynski JA, Weis AL, Bakos T, Yeh IT, Ludueña RF, Lee JC. Effect of $\mathrm{CH}-35$, a novel anti-tumor colchicine analogue, on breast cancer cells overexpressing the $\beta$ III isotype of tubulin. Invest New Drugs, 2016, 34: 129-137.

28. Johnson L, Goping IS, Rieger A, Mane JY, Huzil T, Banerjee A, Luduena R, Hassani B, Winter P, Tuszynski JA. Novel colchicine derivatives and their anti-cancer activity. Curr Top Med Chem. 2017, 17: 2538-2558.

29. Sun Y, Lin X, Chang H. Proliferation inhibition and apoptosis of breast cancer MCF-7 cells under the influence of colchicine. J Buon. 2016, 21: 570-575.

30. Kumar A, Singh B, Mahajan G, Sharma PR, Bharate SB, Mintoo MJ, Mondhe DM. A novel colchicinebased microtubule inhibitor exhibits potent antitumor activity by inducing mitochondrial mediated apoptosis in MIA PaCa-2 pancreatic cancer cells. Tumour Biol. 2016, 37: 13121-13136.

31. Deftereos SG, Vrachatis DA, Angelidis C, Vrettou AR, Sarri EK, Giotaki SG, Varytimiadi E, Kossyvakis C, Kotsia E, Deftereos GS, Doudoumis K, Giannopoulos G. The role of colchicine in treating postoperative and post-catheter ablation atrial fibrillation. Clin Ther. 2019, 41: 21-29.

32. Vrachatis DA, Kossyvakis C, Angelidis C, Panagopoulou V, Sarri EK, Giotaki S, Siasos G, Vavuranakis M, Deftereos SG. Colchicine in post-operative Atrial Fibrillation: A review. Curr Pharm Des. 2018, 24: 695701.

33. Marinaki S, Skalioti C, Boletis JN. Colchicine in renal diseases: Present and future. Curr Pharm Des. 2018, 24: 675-683.

34. Solak Y, Siriopol D, Yildiz A, Yilmaz MI, Ortiz A, Covic A, Kanbay M. Colchicine in renal medicine: New virtues of an Ancient friend. Blood Purif. 2017, 43: 125-135.

35. Demidowich AP, Davis Al, Dedhia N, Yanovski JA. Colchicine to decrease NLRP3-activated inflammation and improve obesity-related metabolic dysregulation. Med Hypotheses. 2016, 92: 67-73. 
36. Mubayed L, Muller BA, Jacobson JL, Hast HA, Nguyen HH. Acute pediatric colchicine toxicity is associated with marked bradydysrhythmias. J Emerg Med. 2018, 55: e65-e69.

37. Alkadi H, Khubeiz MJ, Jbeily R. Colchicine: A review on chemical structure and clinical usage. Infect Disord Drug Targets. 2018, 18: 105-121.

38. Chen B, Liu X, Hu YJ, Zhang DM, Deng L, Lu I, Min L, Ye WC, Li CC. Enantioselective total synthesis of (-)-colchicine, (+)-demecolcinone and metacolchicine: determination of the absolute configurations of the latter two alkaloids. Chem Sci. 2017, 8: 4961-4966.

39. Chien CW, Teng YG, Honda T, Ojima I. Synthesis of colchicinoids and allocolchicinoids through Rh(I)catalyzed $[2+2+2+1]$ and $[2+2+2]$ cycloadditions of o-phenylenetriynes with and without CO. J Org Chem. 2018, 83: 11623-11644.

40. Gumustas M, Polat DÇ, Kiliç CS, Akalin K, Ozkan SA, Coşkun M. Comparison of seeds of Colchicum speciosum and Gloriosa superba in respect to colchicine and colchicoside contents by RP-LC. Nat Prod Commun. 2016, 11: 397-400.

41. Misra A, Shukla PK, Kumar B, Chand J, Kushwaha P, Khalid M, Singh Rawat AK, Srivastava S. Highperformance thin-layer chromatographic-densitometric quantification and recovery of bioactive compounds for identification of elite chemotypes of Gloriosa superba L. collected from Sikkim Himalayas (India). Pharmacogn Mag. 2017, 13: S700-S705.

42. Arun Kumar P, Elangaimannan R. Evaluation of Gloriosa superba for yield attributing characters and quantification of colchicine originated from different agro climatic zones of Tamil Nadu and Andhra Pradesh. IJPCR, 2017; 9: 183-192.

43. Pandey DK, Malik T, Dey A, Singh J Banik RM. Improved growth and colchicine concentration in Gloriosa Superba on mycorrhizal inoculation supplemented with phosphorus-fertilizer. Afr J Tradit Complement Altern Med. 2014, 11: 439-446.

44. Jana S, Shekhawat GS. Critical review on medicinally potent plant species: Gloriosa superba. Fitoterapia, 2011, 82: 293-301.

45. Zarev Y, Foubert K, lonkova I, Apers S, Pieters L. Isolation and structure elucidation of glucosylated colchicinoids from the seeds of Gloriosa superba by LC-DAD-SPE-NMR. J Nat Prod. 2017, 80: 1187-1191.

46. Nguyen PA, Kim JS, Kim JH. The complete chloroplast genome of colchicine plants (Colchicum autumnale L. and Gloriosa superba L.) and its application for identifying the genus. Planta. 2015, 242: 223-237.

47. Sivakumar G. Upstream biomanufacturing of pharmaceutical colchicine. Crit Rev Biotechnol. 2018, 38: 83-92. 
48. Sivakumar G, Kamran A, Phillips GC. Biorhizome: A biosynthetic platform for colchicine manufacturing. Front Plant Sci. 2017, 8: 1137.

49. Nasreen A, Gundlach H, Zenk MH. Incorporation of phenethylisoquinolines into colchicine in isolated seed of Colchicum autumnale. Phytochemistry, 1997, 46: 107-115.

50. Nasreen A Rueffer M, Zenk MH. Cytochrome P-450 dependent formation of isoandrocymbine from autumnaline in colchicine biosynthesis. Tetrahedron Lett. 1996, 37: 8161-8164.

51. Herbert RB, Kattah AE, Knagg E. The biosynthesis of the phenethylisoquinoline alkaloid colchicine. Early and intermediate stage. Tetrahedron Lett. 1990, 46: 7119-7138.

52. Rueffer M, Zenk MH. Microsome-mediated transformation of O-methylandrocymbine to demecolcine and colchicine. FEBS Lett. 1998, 438: 111-113.

53. Samanani N, Park SU, Facchini PJ. Cell type-specific localization of transcripts encoding nine consecutive enzymes involved in protoberberine alkaloid biosynthesis. Plant Cell. 2005, 7: 915-26.

54. Liao D, Wang P, Jia C, Sun P, Qi J, Zhou L, Li X. Identification and developmental expression profiling of putative alkaloid biosynthetic genes in Corydalis yanhusuobulbs. Sci Rep. 2016, 6: 19460.

55. Woodhouse RN, McDonald E, Ramage R, Battersby AR. Biosynthesis. Part 29. Colchicine: studies on the ring expansion step focusing on the fate of the hydrogens at C-3 of autumnaline. J Chem Soc Perkin Trans 1, 1998, 18: 2995-3001.

56. Karamanou M, Tsoucalas G, Pantos K, Androutsos G. Isolating colchicine in 19th century: An old drug revisited. Curr Pharm Des. 2018, 24: 654-658.

57. Cheng L, Li S, Xu X, Hussain J, Yin J, Zhang Y, Li L, Chen X. Identification of differentially expressed genes relevant to corm formation in Sagittaria trifolia. PLoS One, 2013, 8: e54573.

58. Novak SD, Whitehouse GA. Auxin regulates first leaf development and promotes the formation of protocorm trichomes and rhizome-like structures in developing seedlings of Spathoglottis plicata (Orchidaceae). AoB Plants, 2013, 5: pls053.

59. Masuda J, Ozaki Y, Okubo H. Rhizome transition to storage organ is under phytochrome control in lotus (Nelumbo nucifera). Planta, 2007, 226: 909-915.

60. Kim MJ, Nelson W, Soderlund C, Gang DR. Next-generation sequencing-based transcriptional profiling of Sacred Lotus "China Antique". Trop Plant Biol. 2013, 6: 161-179.

61. Yang M, Zhu L, Pan C, Xu L, Liu Y, Ke W, Yang P. Transcriptomic analysis of the regulation of rhizome formation in temperate and tropical lotus (Nelumbo nucifera). Sci Rep. 2015, 5: 13059. 
62. Wang K, Peng H, Lin E, Jin Q, Hua X, Yao S, Bian H, Han N, Pan J, Wang J, Deng M, Zhu M.

Identification of genes related to the development of bamboo rhizome bud. J Exp Bot. 2010, 61: 551-561.

63. Reddy AS, Day IS, Narasimhulu SB, Safadi F, Reddy VS, Golovkin M, Harnly MJ. Isolation and characterization of a novel calmodulin-binding protein from potato. J Biol Chem. 2002, 277: 4206-4214.

64. Yang M, Zhu L, Pan C, Xu L, Liu Y, Ke W, Yang P. Transcriptomic analysis of the regulation of rhizome formation in temperate and Tropical Lotus (Nelumbo nucifera). Sci Rep. 2015, 5: 13059.

65. Navarro C, Abelenda JA, Cruz-Oró E, Cuéllar CA, Tamaki S, Silva J, Shimamoto K, Prat S. Control of flowering and storage organ formation in potato by Flowering Locus T. Nature, 2011, 478: 119-122.

66. Cheng L, Li S, Yin J, Li L, Chen X. Genome-wide analysis of differentially expressed genes relevant to rhizome formation in Lotus root (Nelumbo nucifera Gaertn). PLoS One, 2013, 8: e67116.

67. Yang CQ, Fang X, Wu XM, Mao YB, Wang LJ, Chen XY. Transcriptional regulation of plant secondary metabolism. J Integr Plant Biol. 2012, 54: 703-712.

68. Koo HJ, Gang DR. Suites of terpene synthases explain differential terpenoid production in ginger and turmeric tissues. PLoS One, 2012, 7: e51481.

69. Koo HJ, McDowell ET, Ma X, Greer KA, Kapteyn J, Xie Z, Descour A, Kim H, Yu Y, Kudrna D, Wing RA, Soderlund CA, Gang DR. Ginger and turmeric expressed sequence tags identify signatures for rhizome identity and development and biosynthesis of curcuminoids, gingerols and terpenoid. BMC Plant Biol. 2013, 13: 27.

70. Chen H, Deng C, Nie H, Fan G, He Y. Transcriptome analyses provide insights into the difference of alkaloids biosynthesis in the Chinese goldthread (Coptis chinensis Franch.) from different biotopes. PeerJ. 2017, 5: e3303.

71. Samanani N, Park SU, Facchini PJ. Cell type-specific localization of transcripts encoding nine consecutive enzymes involved in protoberberine alkaloid biosynthesis. Plant Cell. 2005, 7: 915-26.

72. Liao D, Wang P, Jia C, Sun P, Qi J, Zhou L, Li X. Identification and developmental expression profiling of putative alkaloid biosynthetic genes in Corydalis yanhusuobulbs. Sci Rep. 2016, 6: 19460.

73. Zonga Y, Huanga L, Zhanga T, Qina Q, Wanga W, Zhaoa X, Hub F, Fua B, Lia Z. Differential microRNA expression between shoots and rhizomes in Oryza longistaminata using high-throughput RNA sequencing. Crop J. 2014, 2: 102-109.

74. Kang K, Lee K, Park S, Byeon Y, Back K. Molecular cloning of rice serotonin N-acetyltransferase, the penultimate gene in plant melatonin biosynthesis. J Pineal Res. 2013, 55: 7-13. 
75. Byeon Y, Lee HY, Back K. Cloning and characterization of the serotonin N-acetyltransferase-2 gene (SNAT2) in rice (Oryza sativa). J Pineal Res. 2016, 61: 198-207.

76. Choi KB, Morihige T, Shitan N, Yazaki K, Sato F. Molecular cloning and characterization of coclaurine N-methyltransferase from cultured cells of Coptis japonica. J Biol Chem. 2002, 277: 830-835.

77. Torres MA, Hoffarth E, Eugenio L, Savtchouk J, Chen X, Morris JS, Facchini PJ, Ng KK. Structural and functional studies of pavine N-Methyltransferase from Thalictrum flavum reveal insights into substrate recognition and catalytic mechanism. J Biol Chem. 2016, 291: 23403-23415

78. Morris JS, Facchini PJ. Isolation and characterization of reticuline N-Methyltransferase involved in biosynthesis of the aporphine alkaloid magnoflorine in opium poppy. J Biol Chem. 2016, 291: 2341623427.

79. Maier UH, Zenk MH. Colchicine is formed by para-para phenol coupling from autumnaline. Tetrahedron Lett. 1997, 38: 7357-7360.

80. Kilgore MB, Augustin MM, May GD, Crow JA, Kutchan TM. CYP96T1 of Narcissus sp. aff. pseudonarcissus catalyzes formation of the para-para C-C phenol couple in the Amaryllidaceae alkaloids. Front Plant Sci. 2016, 7: 225.

81. Gesell A, Rolf M, Ziegler J, DI'az Cha'vez ML, Huang FC, Kutchan TM. CYP719B1 is salutaridine synthase, the $\mathrm{C}-\mathrm{C}$ phenol-coupling enzyme of morphine biosynthesis in opium poppy. J. Biol. Chem. 2009, 284: $24432-24442$

82. Gesell A, Rolf M, Ziegler J, Díaz Cha'vez ML, Huang FC, Kutchan TM. CYP719B1 is salutaridine synthase, the C-C phenol-coupling enzyme of morphine biosynthesis in opium poppy. J Biol Chem. 2009, 284: 24432-24442.

83. Ikezawa N, Iwasa K, Sato F. Molecular cloning and characterization of CYP80G2, a cytochrome P450 that catalyzes an intramolecular $\mathrm{C}-\mathrm{C}$ phenol coupling of (S)-reticuline in magnoflorine biosynthesis, from cultured Coptis japonica cells. J Biol Chem. 2008, 283: 8810-8821.

84. Kilgore MB, Augustin MM, Starks CM, O’Neil-Johnson M, May GD, Crow JA, Kutchan TM. Cloning and characterization of a norbelladine 4'-0-methyltransferase involved in the biosynthesis of the Alzheimer's drug galanthamine in Narcissus sp. aff. pseudonarcissus. PLoS One, 2014, 9: e103223.

85. Park MR, Chen X, Lang DE, Ng KKS, Facchini PJ. Heterodimeric O-methyltransferases involved in the biosynthesis of noscapine in opium poppy. Plant J. 2018, 95 :252-267.

86. Li Y, Li S, Thodey K, Trenchard I, Cravens A, Smolke CD. Complete biosynthesis of noscapine and halogenated alkaloids in yeast. Proc Natl Acad Sci USA. 2018, 115: E3922-E3931. 
87. Cai B, Siminszky B, Chappell J, Dewey RE, Bush LB. Enantioselective demethylation of nicotine as a mechanism for variable nornicotine composition in tobacco leaf. J Biol Chem. 2012, 287: 42804-42811.

88. Lewis RS, Bowen SW, Keogh MR, Dewey RE. Three nicotine demethylase genes mediate nornicotine biosynthesis in Nicotiana tabacum L.: functional characterization of the CYP82E10 gene. Phytochemistry, 2010, 71: 1988-1998.

89. Liedschulte V, Schwaar JD, Laparra H, Vuarnoz A, Philippon B, Bakaher N, Sierro N, Bovet L, Lang G, Goepfert S. Identification of CYP82E21 as a functional nicotine N-demethylasein tobacco flowers. Phytochemistry, 2016, 131: 9-16.

90. Kellner F, Kim J, Clavijo BJ, Hamilton JP, Childs KL, Vaillancourt B, Cepela J, Habermann M, Steuernage B, Clissold L, McLay K, Buell CR, O'Connor SE. Genome-guided investigation of plant natural product biosynthesis. Plant J. 2015, 82: 680-692.

91. Goossens A, Häkkinen ST, Laakso I, Seppänen-Laakso T, Biondi S, De Sutter V, Lammertyn F, Nuutila AM, Söderlund H, Zabeau M, Inzé D, Oksman-Caldentey KM. A functional genomics approach toward the understanding of secondary metabolism in plant cells. PANS, 2003, 100: 8595-600.

92. Kautsar SA, Suarez Duran HG, Medema MH. Genomic identification and analysis of specialized metabolite biosynthetic gene clusters in plants using PlantiSMASH. Methods Mol Biol. 2018, 1795:173188.

93. Kautsar SA, Suarez Duran HG, Blin K, Osbourn A, Medema MH. PlantiSMASH: automated identification, annotation and expression analysis of plant biosynthetic gene clusters. Nucleic Acids Res. 2017, 45: W55-W63.

94. Ding J, Böhlenius H, Rühl MG, Chen P, Sane S, Zambrano JA, Zheng B, Eriksson ME, Nilsson 0. GIGANTEA-like genes control seasonal growth cessation in Populus. New Phytol. 2018, 218: 1491-1503.

95. de Montaigu A, Coupland G. The timing of GIGANTEA expression during day/night cycles varies with the geographical origin of Arabidopsis accessions. Plant Signal Behav. 2017, 12: e1342026.

96. Tang W, Yan H, Su ZX, Park SC, Liu YJ, Zhang YG, Wang X, Kou M, Ma DF, Kwak SS, Li Q. Cloning and characterization of a novel GIGANTEA gene in sweet potato. Plant Physiol Biochem. 2017, 116: 27-35.

97. Hu T, Wei Q, Wang W, Hu H, Mao W, Zhu Q, Bao C. Genome-wide identification and characterization of CONSTANS-like gene family in radish (Raphanus sativus). PLoS One, 2018, 13: e0204137.

98. Abelenda JA, Cruz-Oró E, Franco-Zorrilla JM, Prat S. Potato StCONSTANS-like1 suppresses storage organ formation by directly activating the FT-like StSP5G repressor. Curr Biol. 2016, 26: 872-881.

99. Teo CJ, Takahashi K, Shimizu K, Shimamoto K, Taoka KI. Potato tuber induction is regulated by interactions between components of a tuberigen complex. Plant Cell Physiol. 2017, 58: 365-374. 
100. Martin A, Adam H, Díaz-Mendoza M, Zurczak M, González-Schain ND, Suárez-López P. Grafttransmissible induction of potato tuberization by the microRNA miR172. Development, 2009, 136: 28732881.

101. Hastilestari BR, Lorenz J, Reid S, Hofmann J, Pscheidt D, Sonnewald U, Sonnewald S. Deciphering source and sink responses of potato plants (Solanum tuberosum L.) to elevated temperatures. Plant Cell Environ. 2018, 41: 2600-2616.

102. Akakpo R, Scarcelli N, Chaïr H, Dansi A, Djedatin G, Thuillet AC, Rhoné B, François O, Alix K, Vigouroux Y. Molecular basis of African yam domestication: analyses of selection point to root development, starch biosynthesis, and photosynthesis related genes. BMC Genomics, 2017, 18: 782.

103. Merelo P, Paredes EB, Heisler MG, Wenkel S. The shady side of leaf development: the role of the REVOLUTA/KANADI1 module in leaf patterning and auxin-mediated growth promotion. Curr Opin Plant Biol. 2017, 35: 111-116.

104. Peng HZ, Lin EP, Sang QL, Yao S, Jin QY, Hua XQ, Zhu MY. Molecular cloning, expression analyses and primary evolution studies of REV- and TB1-like genes in bamboo. Tree Physiol. 2007, 27: 1273-1281.

105. Gao H, Wang Z, Li S, Hou M, Zhou Y, Zhao Y, Li G, Zhao H, Ma H. Genome-wide survey of potato MADS-box genes reveals that StMADS1 and StMADS13 are putative downstream targets of tuberigen StSP6A. BMC Genomics, 2018, 19: 726.

106. Huang Q, Huang X, Deng J, Liu H, Liu Y, Yu K, Huang B. Differential gene expression between leaf and rhizome in Atractylodes lancea: A comparative transcriptome analysis. Front Plant Sci. 2016, 7: 348.

107. Su X, Lu G, Guo H, Zhang K, Li X, Cheng H. The dynamic transcriptome and metabolomics profiling in Verticillium dahliae inoculated Arabidopsis thaliana. Sci Rep. 2018, 8: 15404.

108. Bakshi M, Oelmüller R. WRKY transcription factors. Plant Signal Behav. 2014, 9; e27700.

109. Kumari A, Singh HR, Jha A, Swarnkar MK, Shankar R, Kumar S. Transcriptome sequencing of rhizome tissue of Sinopodophyllum hexandrum at two temperatures. BMC Genomics, 15: 871.

110. Zhang T, Huang L, Wang Y, Wang W, Zhao X, Zhang S, Zhang J, Hu F, Fu B, Li Z. Differential transcriptome profiling of chilling stress response between shoots and rhizomes of Oryza longistaminata using RNA sequencing. PLoS One. 2017, 12: e0188625.

111. Charfeddine M, Saïdi MN, Charfeddine S, Hammami A, Gargouri Bouzid R. Genome-wide analysis and expression profiling of the ERFtranscription factor family in potato (Solanum tuberosum L.). Mol Biotechnol. 2015, 57: 348-358.

112. Wang R, Zhao P, Kong N, Lu R, Pei Y, Huang C, Ma H, Chen Q. Genome-wide identification and characterization of the potato bHLH transcription factor family. Genes (Basel), 2018, 9: pii: E54. 
113. Kodama M, Brinch-Pedersen H, Sharma S, Holme IB, Joernsgaard B, Dzhanfezova T, Amby DB, Vieira FG, Liu S, Gilbert MTP. Identification of transcription factor genes involved in anthocyanin biosynthesis in carrot (Daucus carota L.) using RNA-Seq. BMC Genomics, 2018, 19: 811.

114. Liu F, Yang Y, Gao J, Ma C, Bi Y. A comparative transcriptome analysis of a wild purple potato and its red mutant provides insight into the mechanism of anthocyanin transformation. PLoS One. 2018, 13: e0191406

115. Kumar P, Jaiswal V, Pal T, Singh J, Chauhan RS. Comparative whole-transcriptome analysis in Podophyllum speciesidentifies key transcription factors contributing to biosynthesis of podophyllotoxin in P. hexandrum. Protoplasma, 2017, 254: 217-228.

116. Xie Q, Guo HS, Dallman G, Fang S, Weissman AM, Chua NH. SINAT5 promotes ubiquitin-related degradation of NAC1 to attenuate auxin signals. Nature, 2002, 419: 167-170.

117. Zhang Y, Li D, Wang Y, Zhou R, Wang L, Zhang Y, Yu J, Gong H, You J, Zhang X. Genome-wide identification and comprehensive analysis of the NAC transcription factor family in Sesamum indicum. PLoS One, 2018, 13: e0199262.

118. Phukan UJ, Jeena GS, Shukla RK. WRKY transcription factors: Molecular regulation and stress responses in plants. Front Plant Sci. 2016, 7: 760.

119. Li LQ, Zou X, Deng MS, Peng J, Huang XL, Lu X, Fang CC, Wang XY. Comparative morphology, transcription, and proteomics study revealing the key molecular mechanism of camphor on the potato tuber sprouting effect. Int J Mol Sci. 2017, 18: 2280.

120. Jiang Y, Huang M, Wisniewski M, Li H, Zhang M, Tao X, Liu Y, Zou Y. Transcriptome analysis provides insights into gingerol biosynthesis in ginger (Zingiber officinale). Plant Genome, 2018, 11: 1-11.

121. Hu R, Yu C, Wang X, Jia C, Pei S, He K, He G, Kong Y, Zhou G. De novo transcriptome analysis of Miscanthus iutarioriparius identifies candidate genes in rhizome development. Front Plant Sci. 2017, 8: 492.

122. Teoh KH, Sivakumar G. An expressed sequence tag database analysis of fatty acid genes in Stichococcus bacillaris strain siva2011. In: Kim SK, editor. Biotechnology Advances. London: Academic Press, Elsevier; 2015. p. 429-438.

123. Waterhouse RM, Seppey M, Simão FA, Manni M, loannidis P, Klioutchnikov G, Kriventseva EV, Zdobnov EM. BUSCO applications from quality assessments to gene prediction and phylogenomics. Mol Biol Evol. 2017, 35: 543-548.

124. Götz S, García-Gómez J, Terol J, Williams T, Nagaraj S, Nueda M, Robles M, Talón M, Dopazo J, Conesa A. High-throughput functional annotation and data mining with the Blast2GO suite. Nucleic Acids Res. 2008, 36: 3420-3435. 
125. Shimada MK, Nishida T. A modification of the PHYLIP program: A solution for the redundant cluster problem, and an implementation of an automatic bootstrapping on tree inferred from original data. Mol Phylogenet Evol. 2017, 109: 409-414.

\section{Tables}

Table 1. Predicted candidate colchicine pathway genes in Gloriosa superba and Colchicum autumnale transcriptomes. 
Colchicine

Pathway Genes

Step 1: NMT

G

$\begin{array}{ll}\text { Step 2: P450 } & \text { Colchicum_20101112|29610_ } \\ & \text { Colchicum_20101112|67076_ } \\ & \text { Gloriosa-20120814|30999_1 }\end{array}$

Candidate Gene ID

Gloriosa-20120814|64082_1

Gloriosa-20120814|31585_1

Colchicum_20101112|85_

Colchicum_20101112|85_

Gloriosa-20120814|64082_1

Gloriosa-20120814|12877_1

Gloriosa-20120814|30999_

Gloriosa-20120814|85639_1

Colchicum_20101112|76071_
Reference Gene ID

BAB71802.1 [Coptis japonica]

BAB71802.1 [Coptis japonica]

BAB71802.1 [Coptis japonica]

C3SBW0.1 [Thalictrum

flavum subsp. glaucum]

C3SBW0.1 [Thalictrum

flavum subsp. glaucum]

C3SBW0.1 [Thalictrum

flavum subsp. glaucum]

CYP719B1 [Papaver

somniferum]

CYP96T1 [Narcissus

pseudonarcissus]

CYP80G2 [Coptis japonica]

CYP80G2 [Coptis japonica]

CYP80G2 [Coptis japonica]

Colchicum_20101112|88526_ CYP80G2 [Coptis japonica]

Colchicum_20101112|99151_ C CYP80G2 [Coptis japonica]

Step 3: OMT
AFB74613.1 [Papaver somniferum]

Gloriosa-20120814|31595_1

Gloriosa-20120814|31595_1
Gloriosa-20120814|18437_1

AFB74613.1 [Papaver somniferum]

Gloriosa-20120814|13320_1

Gloriosa-20120814|46280_1

Gloriosa-20120814|6585_1

Gloriosa-20120814|2006_1
AFB74613.1 [Papaver somniferum]

AFB74613.1 [Papaver somniferum]

AFB74613.1 [Papaver somniferum]

AFB74613.1 [Papaver $\begin{array}{ll}\% & \stackrel{e}{-} \\ \text { Identity } & \text { Value }\end{array}$

$57.792 \quad 1.88 \mathrm{E}-$

63

$52.866 \quad 2.28 \mathrm{E}-$

123

$51.862 \quad 4.03 \mathrm{E}-$

127

$48.703 \quad 3.10 \mathrm{E}-$

116

$51.299 \quad 9.25 \mathrm{E}-$

53

$51.29 \quad 7.38 \mathrm{E}-$

111

50

$8.81 \mathrm{E}-$

17

$51.282 \quad 9.95 \mathrm{E}-$

24

$52.778 \quad 1.79 \mathrm{E}-$

06

$52.206 \quad 8.23 \mathrm{E}-$

35

$51.724 \quad 1.24 \mathrm{E}-$

27

50

$2.01 \mathrm{E}-$

07

50

7.77E-

31

55.814

$6.62 \mathrm{E}-$

10

$54.795 \quad 2.60 \mathrm{E}-$

21

52

$5.10 \mathrm{E}-$

20

$51.429 \quad 3.68 \mathrm{E}-$

07

$51.282 \quad 4.34 \mathrm{E}-$

08

$51.163 \quad 7.24 \mathrm{E}-$ 


\begin{tabular}{|c|c|c|c|}
\hline Gloriosa-20120814|16875_1 & $\begin{array}{l}\text { AFB74613.1 [Papaver } \\
\text { somniferum] }\end{array}$ & 50.909 & $\begin{array}{l}1.37 \mathrm{E}- \\
33\end{array}$ \\
\hline Gloriosa-20120814|31794_1 & $\begin{array}{l}\text { AFB74613.1 [Papaver } \\
\text { somniferum] }\end{array}$ & 50.847 & $\begin{array}{l}1.32 \mathrm{E}- \\
15\end{array}$ \\
\hline Gloriosa-20120814|36043_1 & $\begin{array}{l}\text { AFB74613.1 [Papaver } \\
\text { somniferum] }\end{array}$ & 50.588 & $\begin{array}{l}4.80 \mathrm{E}- \\
22\end{array}$ \\
\hline Gloriosa-20120814|25318_1 & Q9LEL5.1 [Coptis japonica] & 62.162 & $\begin{array}{l}5.4 \mathrm{E}- \\
11\end{array}$ \\
\hline Gloriosa-20120814|2864_1 & Q9LEL5.1 [Coptis japonica] & 50.725 & $\begin{array}{l}4.88 \mathrm{E}- \\
16\end{array}$ \\
\hline Gloriosa-20120814|25750_1 & Q9LEL5.1 [Coptis japonica] & 50.685 & $\begin{array}{l}1.15 \mathrm{E}- \\
22\end{array}$ \\
\hline Colchicum_20101112|51346_ & Q9LEL5.1 [Coptis japonica] & 53.333 & $\begin{array}{l}1.16 \mathrm{E}- \\
28\end{array}$ \\
\hline Colchicum_20101112|72754_ & Q9LEL5.1 [Coptis japonica] & 52.809 & $\begin{array}{l}1.86 \mathrm{E}- \\
20\end{array}$ \\
\hline Colchicum_20101112|59167_ & Q9LEL5.1 [Coptis japonica] & 50.485 & $\begin{array}{l}9.05 \mathrm{E}- \\
29\end{array}$ \\
\hline Gloriosa-20120814|82787_1 & $\begin{array}{l}\text { A0A077EWA5.1 [Narcissus } \\
\text { pseudonarcissus] }\end{array}$ & 72.857 & $\begin{array}{l}1.42 \mathrm{E}- \\
26\end{array}$ \\
\hline Gloriosa-20120814|42115_1 & $\begin{array}{l}\text { A0A077EWA5.1 [Narcissus } \\
\text { pseudonarcissus] }\end{array}$ & 68.636 & $\begin{array}{l}2.31 \mathrm{E}- \\
109\end{array}$ \\
\hline Gloriosa-20120814|238_1 & $\begin{array}{l}\text { A0A077EWA5.1 [Narcissus } \\
\text { pseudonarcissus] }\end{array}$ & 64.017 & $\begin{array}{l}3.14 \mathrm{E}- \\
104\end{array}$ \\
\hline Gloriosa-20120814|10195_1 & $\begin{array}{l}\text { A0A077EWA5. } 1 \text { [Narcissus } \\
\text { pseudonarcissus] }\end{array}$ & 59.031 & $\begin{array}{l}1.08 \mathrm{E}- \\
92\end{array}$ \\
\hline Colchicum_20101112|68404_ & $\begin{array}{l}\text { A0A077EWA5.1 [Narcissus } \\
\text { pseudonarcissus] }\end{array}$ & 71.25 & $\begin{array}{l}2.12 \mathrm{E}- \\
35\end{array}$ \\
\hline Colchicum_20101112|14671_ & $\begin{array}{l}\text { A0A077EWA5.1 [Narcissus } \\
\text { pseudonarcissus] }\end{array}$ & 67.234 & $\begin{array}{l}3.44 \mathrm{E}- \\
114\end{array}$ \\
\hline Colchicum_20101112|34468_ & $\begin{array}{l}\text { A0A077EWA5.1 [Narcissus } \\
\text { pseudonarcissus] }\end{array}$ & 65.236 & $\begin{array}{l}3.19 \mathrm{E}- \\
108\end{array}$ \\
\hline Colchicum_20101112|9022_ & $\begin{array}{l}\text { A0A077EWA5.1 [Narcissus } \\
\text { pseudonarcissus] }\end{array}$ & 63.983 & $\begin{array}{l}4.49 \mathrm{E}- \\
108\end{array}$ \\
\hline Colchicum_20101112|75393_ & $\begin{array}{l}\text { A0A077EWA5.1 [Narcissus } \\
\text { pseudonarcissus] }\end{array}$ & 63.194 & $\begin{array}{l}2.07 \mathrm{E}- \\
62\end{array}$ \\
\hline Colchicum_20101112|29556_ & $\begin{array}{l}\text { A0A077EWA5.1 [Narcissus } \\
\text { pseudonarcissus] }\end{array}$ & 59.633 & $\begin{array}{l}9.11 \mathrm{E}- \\
89\end{array}$ \\
\hline
\end{tabular}




\begin{tabular}{|c|c|c|c|c|}
\hline & Colchicum_20101112|23611_ & $\begin{array}{l}\text { A0A077EWA5.1 [Narcissus } \\
\text { pseudonarcissus] }\end{array}$ & 58.15 & $\begin{array}{l}1.12 \mathrm{E}- \\
90\end{array}$ \\
\hline \multirow[t]{11}{*}{ Step 4: P450 } & Gloriosa-20120814|5091_1 & $\begin{array}{l}\text { CYP82E5v2 [Nicotiana } \\
\text { tabacum] }\end{array}$ & 52.326 & $\begin{array}{l}1.27 \mathrm{E}- \\
24\end{array}$ \\
\hline & Colchicum_20101112|74349_ & $\begin{array}{l}\text { CYP82E5v2 [Nicotiana } \\
\text { tabacum] }\end{array}$ & 55.172 & $\begin{array}{l}4.87 \mathrm{E}- \\
29\end{array}$ \\
\hline & Colchicum_20101112|75506_ & $\begin{array}{l}\text { CYP82E5v2 [Nicotiana } \\
\text { tabacum] }\end{array}$ & 50.962 & $\begin{array}{l}6.75 \mathrm{E}- \\
34\end{array}$ \\
\hline & Gloriosa-20120814|5091_1 & $\begin{array}{l}\text { CYP82E10 [Nicotiana } \\
\text { tabacum] }\end{array}$ & 51.163 & $\begin{array}{l}6.91 \mathrm{E}- \\
25\end{array}$ \\
\hline & Colchicum_20101112|74349_ & $\begin{array}{l}\text { CYP82E10 [Nicotiana } \\
\text { tabacum] }\end{array}$ & 55.172 & $\begin{array}{l}4.41 \mathrm{E}- \\
29\end{array}$ \\
\hline & Colchicum_20101112|54622_ & $\begin{array}{l}\text { CYP82E10 [Nicotiana } \\
\text { tabacum] }\end{array}$ & 51.24 & $\begin{array}{l}3.41 \mathrm{E}- \\
34\end{array}$ \\
\hline & Colchicum_20101112|39301_ & $\begin{array}{l}\text { CYP82E10 [Nicotiana } \\
\text { tabacum] }\end{array}$ & 50 & $\begin{array}{l}4.66 \mathrm{E}- \\
22\end{array}$ \\
\hline & Colchicum_20101112|75506_ & $\begin{array}{l}\text { CYP82E10 [Nicotiana } \\
\text { tabacum] }\end{array}$ & 50 & $\begin{array}{l}4.23 \mathrm{E}- \\
34\end{array}$ \\
\hline & Gloriosa-20120814|5091_1 & $\begin{array}{l}\text { CYP82E4 [Nicotiana } \\
\text { tabacum] }\end{array}$ & 53.488 & $\begin{array}{l}1.63 \mathrm{E}- \\
24\end{array}$ \\
\hline & Colchicum_20101112|74349_ & $\begin{array}{l}\text { CYP82E4 [Nicotiana } \\
\text { tabacum] }\end{array}$ & 54.023 & $\begin{array}{l}1.36 \mathrm{E}- \\
27\end{array}$ \\
\hline & Colchicum_20101112|75506_ & $\begin{array}{l}\text { CYP82E4 [Nicotiana } \\
\text { tabacum] }\end{array}$ & 50 & $\begin{array}{l}8.59 \mathrm{E}- \\
32\end{array}$ \\
\hline \multirow[t]{7}{*}{ Step 5: NAT } & Gloriosa-20120814|32279_1 & $\begin{array}{l}\text { BAG90782.1 [Oryza sativa } \\
\text { Japonica Group] }\end{array}$ & 67.702 & $\begin{array}{l}1.42 \mathrm{E}- \\
74\end{array}$ \\
\hline & Colchicum_20101112|8688_ & $\begin{array}{l}\text { BAG90782.1 [Oryza sativa } \\
\text { Japonica Group] }\end{array}$ & 71.034 & $\begin{array}{l}3.05 \mathrm{E}- \\
67\end{array}$ \\
\hline & Gloriosa-20120814|70209_1 & $\begin{array}{l}\text { Q5KQI6.1 [Oryza sativa } \\
\text { Japonica Group] }\end{array}$ & 69.136 & $\begin{array}{l}1.54 \mathrm{E}- \\
108\end{array}$ \\
\hline & Gloriosa-20120814|51165_1 & $\begin{array}{l}\text { Q5KQI6.1 [Oryza sativa } \\
\text { Japonica Group] }\end{array}$ & 68.016 & $\begin{array}{l}2.70 \mathrm{E}- \\
106\end{array}$ \\
\hline & Gloriosa-20120814|30717_1 & $\begin{array}{l}\text { Q5KQI6.1 [Oryza sativa } \\
\text { Japonica Group] }\end{array}$ & 64.615 & $\begin{array}{l}6.09 \mathrm{E}- \\
104\end{array}$ \\
\hline & Colchicum_20101112|6813_ & $\begin{array}{l}\text { Q5KQI6.1 [Oryza sativa } \\
\text { Japonica Group] }\end{array}$ & 76.768 & $\begin{array}{l}5.79 \mathrm{E}- \\
109\end{array}$ \\
\hline & Colchicum_20101112|37095_ & $\begin{array}{l}\text { Q5KQI6.1 [Oryza sativa } \\
\text { Japonica Group] }\end{array}$ & 70.476 & $\begin{array}{l}1.26 \mathrm{E}- \\
102\end{array}$ \\
\hline
\end{tabular}


Table 2. Predicted candidate rhizome developmental genes in Gloriosa superba and Colchicum autumnale transcriptomes. 


\section{Rhizome}

\section{Developmental Candidate Gene ID}

Genes

GIGANTEA

Colchicum_20101112|2617_

Reference Gene ID

$\%$

Identity Value

GIGANTEA

\begin{tabular}{|c|c|c|c|c|}
\hline & Gloriosa-20120814I11998_1 & $\begin{array}{l}\text { XP_010268589.1 Nelumbo } \\
\text { nucifera }\end{array}$ & 76.132 & 0 \\
\hline & Gloriosa-20120814|8521_1 & $\begin{array}{l}\text { PGSC0003DMT } 4000048370 \\
\text { Solanum tuberosum* }\end{array}$ & 69.743 & 0 \\
\hline & Colchicum_20101112|2617_ & $\begin{array}{l}\text { PGSC0003DMT44000048370 } \\
\text { S. tuberosum* }\end{array}$ & 82.609 & $\begin{array}{l}1.68 \mathrm{E}- \\
173\end{array}$ \\
\hline \multirow[t]{13}{*}{ CONSTANS } & Gloriosa-20120814|51159_1 & $\begin{array}{l}\text { XP_010261698.1 Nelumbo } \\
\text { nucifera }\end{array}$ & 84.091 & $\begin{array}{l}7.14 \mathrm{E}- \\
12\end{array}$ \\
\hline & Colchicum_20101112|3159_ & $\begin{array}{l}\text { XP_010257847.1 Nelumbo } \\
\text { nucifera }\end{array}$ & 81.818 & $\begin{array}{l}1.79 \mathrm{E}- \\
11\end{array}$ \\
\hline & Gloriosa-20120814|51159_1 & $\begin{array}{l}\text { PGSC0003DMT } 400067656 \\
\text { S. tuberosum* }\end{array}$ & 75.51 & $\begin{array}{l}1.14 \mathrm{E}- \\
13\end{array}$ \\
\hline & Colchicum_20101112|3159_ & $\begin{array}{l}\text { PGSC0003DMT400026065 } \\
\text { S. tuberosum* }\end{array}$ & 81.818 & $\begin{array}{l}4.61 \mathrm{E}- \\
12\end{array}$ \\
\hline & Gloriosa-20120814|17037_1 & $\begin{array}{l}\text { NP_001274795.1 Solanum } \\
\text { tuberosum }\end{array}$ & 72.5 & $\begin{array}{l}4.85 \mathrm{E}- \\
30\end{array}$ \\
\hline & Gloriosa-20120814|51159_1 & $\begin{array}{l}\text { NP_001274795.1 Solanum } \\
\text { tuberosum }\end{array}$ & 68.627 & $\begin{array}{l}3.75 \mathrm{E}- \\
10\end{array}$ \\
\hline & Gloriosa-20120814|18001_1 & $\begin{array}{l}\text { NP_001274795.1 Solanum } \\
\text { tuberosum }\end{array}$ & 68.627 & $\begin{array}{l}4.24 \mathrm{E}- \\
10\end{array}$ \\
\hline & Gloriosa-20120814|20079_1 & $\begin{array}{l}\text { NP_001274795.1 Solanum } \\
\text { tuberosum }\end{array}$ & 67.442 & $\begin{array}{l}2.97 \mathrm{E}- \\
11\end{array}$ \\
\hline & Gloriosa-20120814|72100_1 & $\begin{array}{l}\text { NP_001274795.1 Solanum } \\
\text { tuberosum }\end{array}$ & 64 & $\begin{array}{l}4.59 \mathrm{E}- \\
29\end{array}$ \\
\hline & Colchicum_20101112|3159_ & $\begin{array}{l}\text { NP_001274795.1 Solanum } \\
\text { tuberosum }\end{array}$ & 81.818 & $\begin{array}{l}2.96 \mathrm{E}- \\
10\end{array}$ \\
\hline & Colchicum_20101112|5391_ & $\begin{array}{l}\text { NP_001274795.1 Solanum } \\
\text { tuberosum }\end{array}$ & 73.75 & $\begin{array}{l}1.17 \mathrm{E}- \\
23\end{array}$ \\
\hline & Colchicum_20101112|27602_ & $\begin{array}{l}\text { NP_001274795.1 Solanum } \\
\text { tuberosum }\end{array}$ & 79.365 & $\begin{array}{l}7.90 \mathrm{E}- \\
29\end{array}$ \\
\hline & Colchicum_20101112|26221_ & $\begin{array}{l}\text { NP_001274795.1 Solanum } \\
\text { tuberosum }\end{array}$ & 71.795 & $\begin{array}{l}1.62 \mathrm{E}- \\
12\end{array}$ \\
\hline Phytochrome B & Gloriosa-20120814|36050_1 & $\begin{array}{l}\text { XP_010267948.1 Nelumbo } \\
\text { nucifera }\end{array}$ & 81.445 & 0 \\
\hline
\end{tabular}


XP_010267948.1 Nelumbo nucifera

PGSC0003DMT400061712 S. tuberosum*

PGSC0003DMT400061712 S. tuberosum*

Sucrose

Synthase

XP_010271909.1 Nelumbo nucifera

XP_010271909.1 Nelumbo nucifera

XP_010271909.1 Nelumbo nucifera

XP_010271909.1 Nelumbo nucifera

XP_010271909.1 Nelumbo nucifera

XP_010271909.1 Nelumbo nucifera

PGSC0003DMT400007506 S. tuberosum ${ }^{\star}$

PGSC0003DMT400007506 S. tuberosum*

Flowering

Locus $T$

Colchicum_20101112|8829_

Colchicum_20101112|22914_

XP_010268289.1 Nelumbo nucifera

XP_010268289.1 Nelumbo
Colchicum_20101112|1221_

Gloriosa-20120814|85746_1

Colchicum_20101112|1221_
Gloriosa-20120814|69933_1

Colchicum_20101112|13826_

Colchicum_20101112|593_

Colchicum_20101112|2693_

Colchicum_20101112|33099_

Colchicum_20101112|583_

Gloriosa-20120814|9073_1

Colchicum_20101112|2693_
Gloriosa-20120814|55554_1

Colchicum_20101112|22914_

Colchicum_20101112|8829_

(1)

Gloriosa-20120814|55554_1

PGSC0003DMT400060057

S. tuberosum*

$80.142 \quad 0$

$80.927 \quad 0$

$79.539 \quad 0$

$81.886 \quad 0$

$81.39 \quad 0$

$81.39-0$

$80.15 \quad 0$ nucifera

XP_010268289.1 Nelumbo nucifera

$81.404 \quad 0$

$71.535 \quad 0$

$71.411 \quad 0$

$76.923 \quad 0$

PGSC0003DMT400060057

S. tuberosum*

PGSC0003DMT400060057

S. tuberosum*

$76.289 \quad 0$

$80.925 \quad 1.75 \mathrm{E}-$ 109

$86.232 \quad 1.56 \mathrm{E}-$ 92

$83.815 \quad 2.85 \mathrm{E}-$ 113

$78.788 \quad 9.86 \mathrm{E}-$ 81

NP_001274897.1 Solanum tuberosum

73.81

Colchicum_20101112|8829_

Colchicum_20101112|22914_ NP_001274897.1 Solanum tuberosum

77.273

NP_001274897.1 Solanum

tuberosum

74.405

Gloriosa-20120814|55554_1 


\begin{tabular}{cllll}
\hline & Gloriosa-20120814|55004_1 & $\begin{array}{l}\text { NP_001274897.1 Solanum } \\
\text { tuberosum }\end{array}$ & 67.066 & $\begin{array}{l}\text { 3.03E- } \\
82\end{array}$ \\
\hline & Gloriosa-20120814|26010_1 & $\begin{array}{l}\text { NP_001274897.1 Solanum } \\
\text { tuberosum }\end{array}$ & 64.968 & $\begin{array}{l}1.36 \mathrm{E}- \\
71\end{array}$ \\
\hline Gloriosa-20120814|45011_1 & $\begin{array}{l}\text { NP_001274897.1 Solanum } \\
\text { tuberosum }\end{array}$ & 72.034 & $\begin{array}{l}4.46 \mathrm{E}- \\
63\end{array}$ \\
\hline Gloriosa-20120814|52745_1 & $\begin{array}{l}\text { NP_001274897.1 Solanum } \\
\text { tuberosum }\end{array}$ & 60 & $1.55 \mathrm{E}-$ \\
\hline REVOLUTA & Gloriosa-20120814|11056_1 & $\begin{array}{l}\text { XP_010247499.1 Nelumbo } \\
\text { nucifera }\end{array}$ & 86.244 & 0 \\
\hline & Colchicum_20101112|467_ & $\begin{array}{l}\text { XP_010247499.1 Nelumbo } \\
\text { nucifera }\end{array}$ & 85.221 & 0 \\
\hline Colchicum_20101112|467_ & $\begin{array}{l}\text { PGSC0003DMT400030829 } \\
\text { S. tuberosum* }\end{array}$ & 81.02 & 0 \\
\hline Gloriosa-20120814|17486_1 & $\begin{array}{l}\text { PGSC0003DMT400030829 } \\
\text { S. tuberosum* }\end{array}$ & 81.182 & 0 \\
\hline Gloriosa-20120814|15982_1 & $\begin{array}{l}\text { AAY32332.1 Phyllostachys } \\
\text { praecox }\end{array}$ & 78.851 & 0 \\
\hline Colchicum_20101112|6503_ & $\begin{array}{l}\text { AAY32332.1 Phyllostachys } \\
\text { praecox }\end{array}$ & 78.091 & 0 \\
\hline
\end{tabular}

*Sequence from Solanum tuberosum transcriptome [https://plants.ensembl.org/Solanum_tuberosum/Info/Index]

Table 3. Predicted candidate transcription factors in Gloriosa superba and Colchicum autumnale transcriptomes. 
Transcription Candidate Gene ID

Factors

\begin{tabular}{|c|c|c|c|c|}
\hline \multirow[t]{4}{*}{ MADS-box } & Gloriosa-20120814|19828_1 & $\begin{array}{l}\text { XP_010272608.1 Nelumbo } \\
\text { nucifera }\end{array}$ & 77.366 & $\begin{array}{l}2.02 \mathrm{E}- \\
138\end{array}$ \\
\hline & Gloriosa-20120814|35037_1 & $\begin{array}{l}\text { PGSC0003DMT } 400000026 \\
\text { Solanum tuberosum* }\end{array}$ & 82.432 & $\begin{array}{l}3.32 \mathrm{E}- \\
42\end{array}$ \\
\hline & Gloriosa-20120814|39825_1 & $\begin{array}{l}\text { PGSC0003DMT400000026 } \\
\text { Solanum tuberosum* }\end{array}$ & 60.317 & $\begin{array}{l}9.37 \mathrm{E}- \\
23\end{array}$ \\
\hline & Colchicum_20101112|22985_ & $\begin{array}{l}\text { PGSC0003DMT } 400000026 \\
\text { Solanum tuberosum* }\end{array}$ & 81.159 & $\begin{array}{l}3.61 \mathrm{E}- \\
37\end{array}$ \\
\hline \multirow[t]{9}{*}{ AP2-EREBP } & Colchicum_20101112|4936_ & $\begin{array}{l}\text { XP_010263474.1 Nelumbo } \\
\text { nucifera }\end{array}$ & 73.684 & $\begin{array}{l}3.88 \mathrm{E}- \\
88\end{array}$ \\
\hline & Gloriosa-20120814|45526_1 & $\begin{array}{l}\text { XP_010271250.1 Nelumbo } \\
\text { nucifera }\end{array}$ & 86.047 & $\begin{array}{l}9.56 \mathrm{E}- \\
22\end{array}$ \\
\hline & Gloriosa-20120814|54352_1 & $\begin{array}{l}\text { XP_010271250.1 Nelumbo } \\
\text { nucifera }\end{array}$ & 82.353 & $\begin{array}{l}1.69 \mathrm{E}- \\
16\end{array}$ \\
\hline & Gloriosa-20120814|7267_1 & $\begin{array}{l}\text { XP_010271250.1 Nelumbo } \\
\text { nucifera }\end{array}$ & 68.831 & $\begin{array}{l}3.04 \mathrm{E}- \\
32\end{array}$ \\
\hline & Gloriosa-20120814|58739_1 & $\begin{array}{l}\text { XP_010271250.1 Nelumbo } \\
\text { nucifera }\end{array}$ & 66.667 & $\begin{array}{l}1.15 \mathrm{E}- \\
18\end{array}$ \\
\hline & Gloriosa-20120814|77954_1 & $\begin{array}{l}\text { XP_010271250.1 Nelumbo } \\
\text { nucifera }\end{array}$ & 65.854 & $\begin{array}{l}4.44 \mathrm{E}- \\
33\end{array}$ \\
\hline & Gloriosa-20120814|23228_1 & $\begin{array}{l}\text { PGSC0003DMT400016585 } \\
\text { Solanum tuberosum* }\end{array}$ & 80.905 & $\begin{array}{l}1.16 \mathrm{E}- \\
97\end{array}$ \\
\hline & Colchicum_20101112|10921_ & $\begin{array}{l}\text { PGSC0003DMT400016585 } \\
\text { Solanum tuberosum* }\end{array}$ & 75.701 & $\begin{array}{l}6.49 \mathrm{E}- \\
99\end{array}$ \\
\hline & Colchicum_20101112|4936_ & $\begin{array}{l}\text { PGSC0003DMT400016584 } \\
\text { Solanum tuberosum* }\end{array}$ & 83.929 & $\begin{array}{l}5.12 \mathrm{E}- \\
64\end{array}$ \\
\hline \multirow[t]{4}{*}{ bHLH } & Gloriosa-20120814|6279_1 & $\begin{array}{l}\text { XP_010257880.1 Nelumbo } \\
\text { nucifera }\end{array}$ & 89.744 & $\begin{array}{l}3.68 \mathrm{E}- \\
18\end{array}$ \\
\hline & Colchicum_20101112|7042_ & $\begin{array}{l}\text { XP_010273628.1 Nelumbo } \\
\text { nucifera }\end{array}$ & 81.818 & $\begin{array}{l}1.93 \mathrm{E}- \\
48\end{array}$ \\
\hline & Gloriosa-20120814|53746_1 & $\begin{array}{l}\text { PGSC0003DMT400022702 } \\
\text { Solanum tuberosum* }\end{array}$ & 88.889 & $\begin{array}{l}1.27 \mathrm{E}- \\
11\end{array}$ \\
\hline & Colchicum_20101112|21881_ & $\begin{array}{l}\text { PGSC0003DMT400022701 } \\
\text { Solanum tuberosum* }\end{array}$ & 86.364 & $\begin{array}{l}9.32 \mathrm{E}- \\
08\end{array}$ \\
\hline \multirow[t]{2}{*}{ MYB } & Gloriosa-20120814|15461_1 & $\begin{array}{l}\text { XP_010277005.1 Nelumbo } \\
\text { nucifera }\end{array}$ & 90.698 & $\begin{array}{l}8.02 \mathrm{E}- \\
86\end{array}$ \\
\hline & Colchicum_20101112|11314_ & XP_010253806.1 Nelumbo & 87.097 & 1.43E- \\
\hline
\end{tabular}

\section{Reference Gene ID}

$\%$ Identity $\stackrel{e}{\text { Value }}$

MADS-box

$$
\text { Glo }
$$




\begin{tabular}{|c|c|c|c|c|}
\hline & Gloriosa-20120814|15461_1 & $\begin{array}{l}\text { PGSC0003DMT400012203 } \\
\text { Solanum tuberosum* }\end{array}$ & 90.698 & $\begin{array}{l}1.34 \mathrm{E}- \\
87\end{array}$ \\
\hline & Colchicum_20101112|20668_ & $\begin{array}{l}\text { PGSC0003DMT400017709 } \\
\text { Solanum tuberosum* }\end{array}$ & 86.301 & $\begin{array}{l}2.98 \mathrm{E}- \\
41\end{array}$ \\
\hline \multirow[t]{4}{*}{ NAC } & Gloriosa-20120814|28710_1 & $\begin{array}{l}\text { XP_010243512.1 Nelumbo } \\
\text { nucifera }\end{array}$ & 84.397 & $\begin{array}{l}1.10 \mathrm{E}- \\
89\end{array}$ \\
\hline & Colchicum_20101112|44481_ & $\begin{array}{l}\text { XP_010270427.1 Nelumbo } \\
\text { nucifera }\end{array}$ & 71.429 & $\begin{array}{l}1.09 \mathrm{E}- \\
07\end{array}$ \\
\hline & Gloriosa-20120814|18396_1 & $\begin{array}{l}\text { PGSC0003DMT400045294 } \\
\text { Solanum tuberosum* }\end{array}$ & 81.212 & $\begin{array}{l}2.64 \mathrm{E}- \\
101\end{array}$ \\
\hline & Colchicum_20101112|794_ & $\begin{array}{l}\text { PGSC0003DMT400079789 } \\
\text { Solanum tuberosum* }\end{array}$ & 71.429 & $\begin{array}{l}7.85 \mathrm{E}- \\
91\end{array}$ \\
\hline \multirow[t]{6}{*}{ WRKY } & Colchicum_20101112|22998_ & $\begin{array}{l}\text { XP_010258216.1 Nelumbo } \\
\text { nucifera }\end{array}$ & 80.952 & $\begin{array}{l}5.53 \mathrm{E}- \\
07\end{array}$ \\
\hline & Gloriosa-20120814|20164_1 & $\begin{array}{l}\text { XP_010258120.1 Nelumbo } \\
\text { nucifera }\end{array}$ & 76.596 & $\begin{array}{l}7.13 \mathrm{E}- \\
50\end{array}$ \\
\hline & Gloriosa-20120814|66904_1 & $\begin{array}{l}\text { PGSC0003DMT400028529 } \\
\text { Solanum tuberosum* }\end{array}$ & 77.419 & $\begin{array}{l}3.60 \mathrm{E}- \\
28\end{array}$ \\
\hline & Colchicum_20101112|22998_ & $\begin{array}{l}\text { PGSC0003DMT400072835 } \\
\text { Solanum tuberosum* }\end{array}$ & 80.952 & $\begin{array}{l}5.16 \mathrm{E}- \\
07\end{array}$ \\
\hline & Colchicum_20101112|49701_ & $\begin{array}{l}\text { ALD83482.1 } \\
\text { Sinopodophyllum hexandrum }\end{array}$ & 80 & $\begin{array}{l}2.46 \mathrm{E}- \\
14\end{array}$ \\
\hline & Colchicum_20101112|3957_ & $\begin{array}{l}\text { ALD83482.1 } \\
\text { Sinopodophyllum hexandrum }\end{array}$ & 76 & $\begin{array}{l}2.38 \mathrm{E}- \\
19\end{array}$ \\
\hline
\end{tabular}

*Sequence from Solanum tuberosum transcriptome

[https://plants.ensembl.org/Solanum_tuberosum/Info/Index]

\section{Figures}




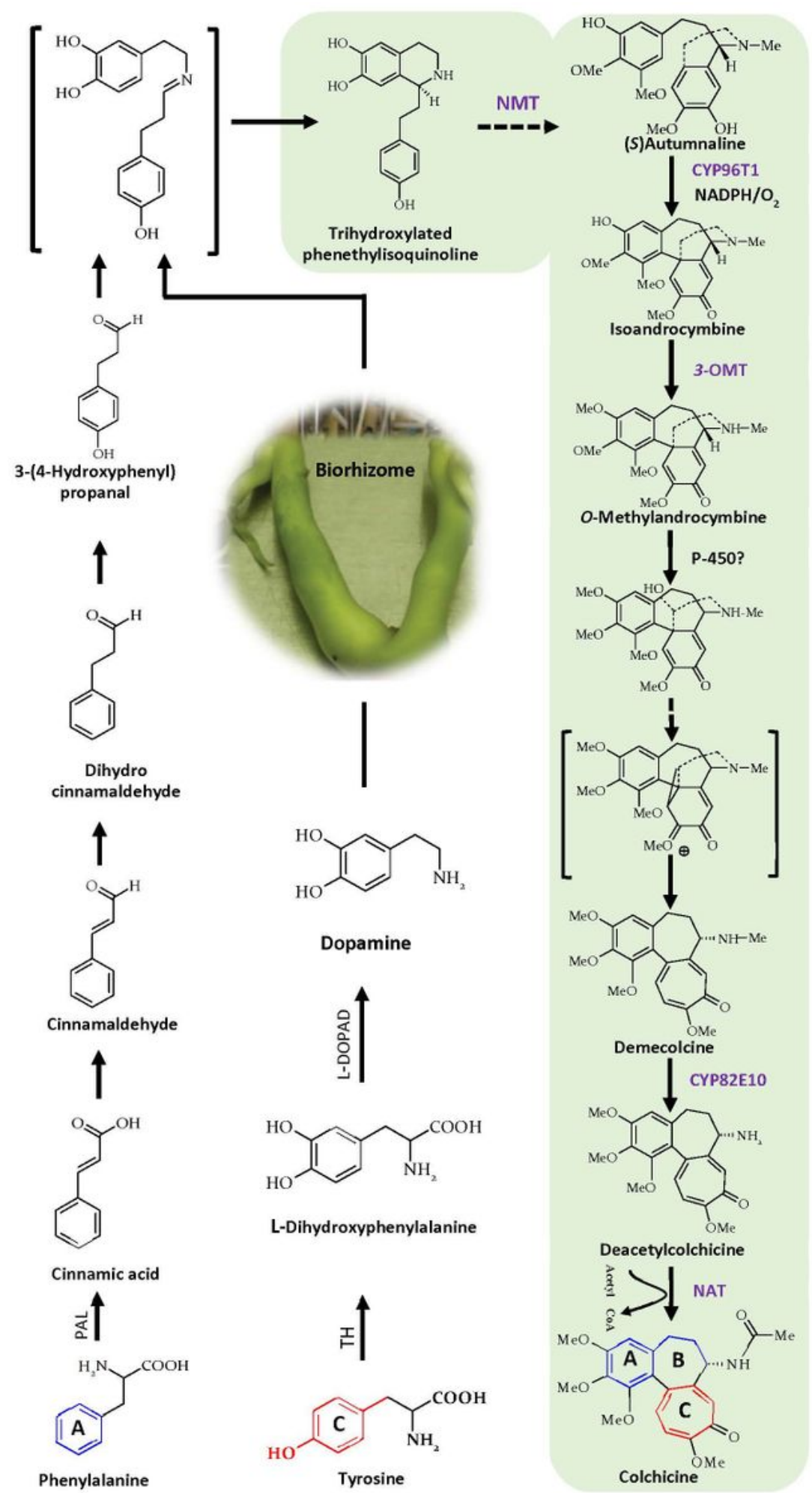

\section{Figure 1}

Proposed colchicine pathway in Gloriosa superba. TH: Tyrosine hydroxylase; L-DOPAD: LDihydroxyphenylalanine decarboxylase; PAL: Phenylalanine ammonia-lyase; NMT: N-methyltransferase; OMT: O-methyltransferase; NAT: N- acetyltransferase [47] 


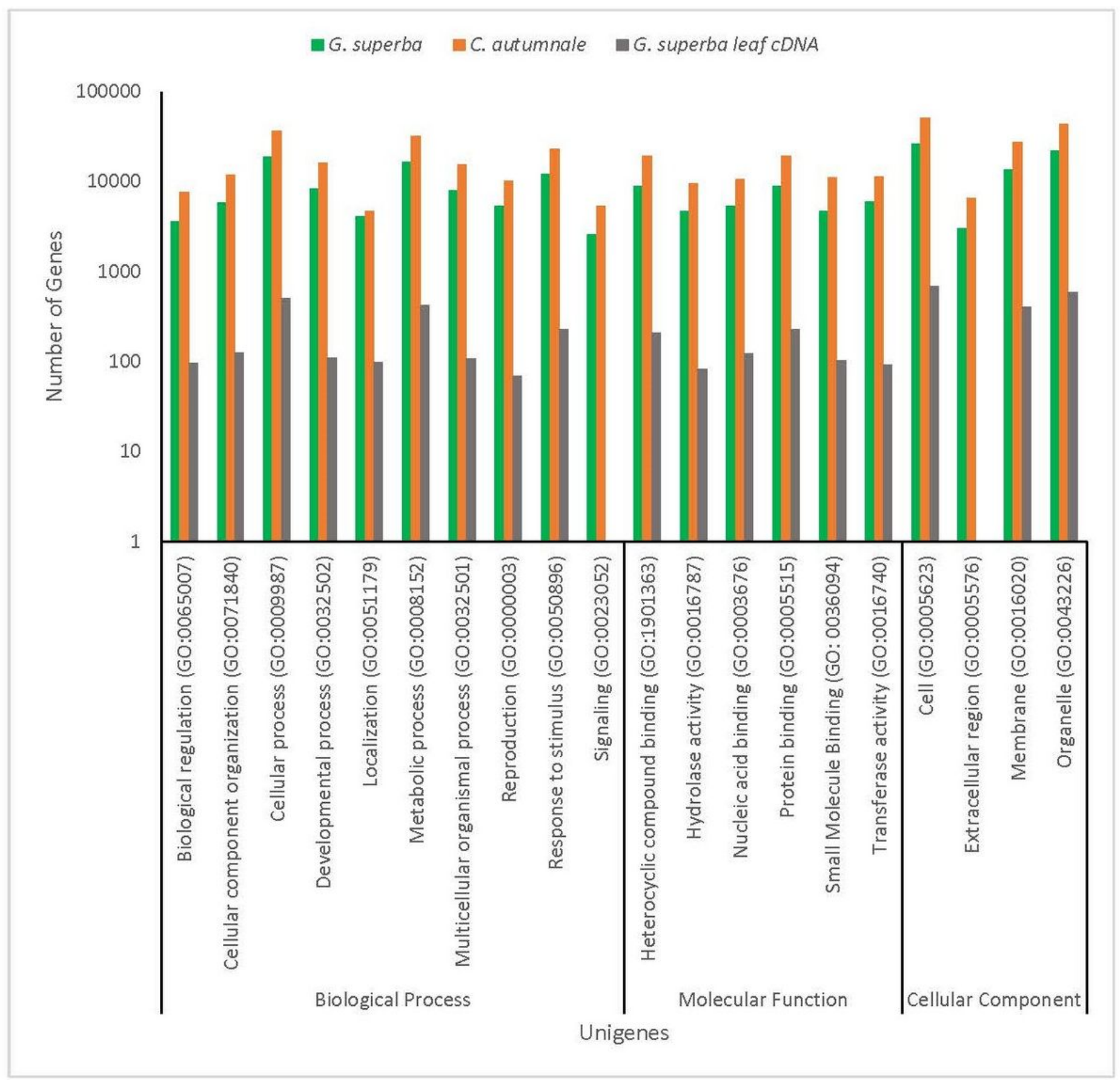

Figure 2

Gene ontology (GO) annotation of G. superba and Colchicum autumnale transcriptomes. 


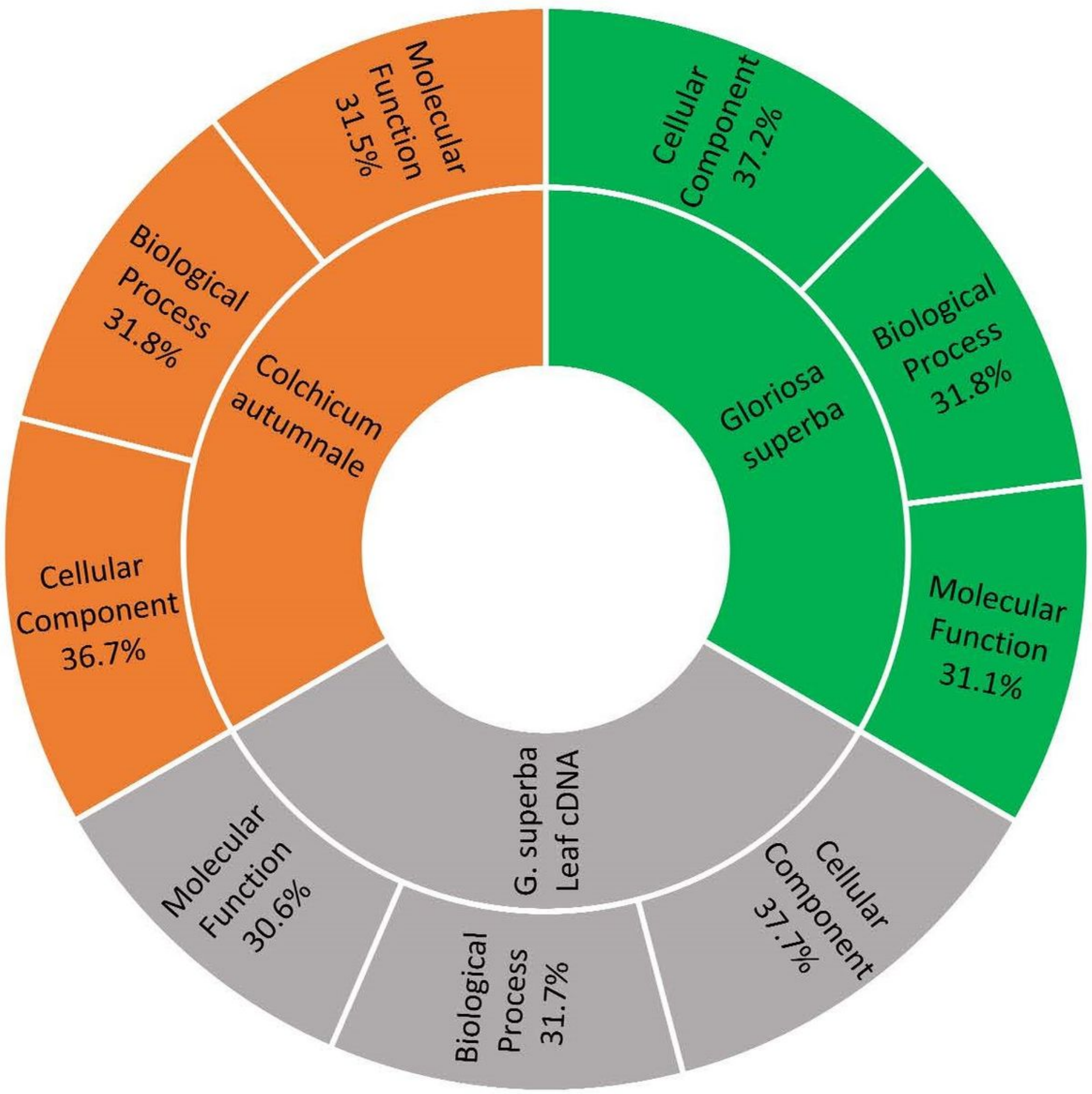

Figure 3

Percentage of gene ontology annotations for molecular function, biological process, and cellular components in G. superba and C. autumnale transcriptome and G. superba leaf cDNA library. 

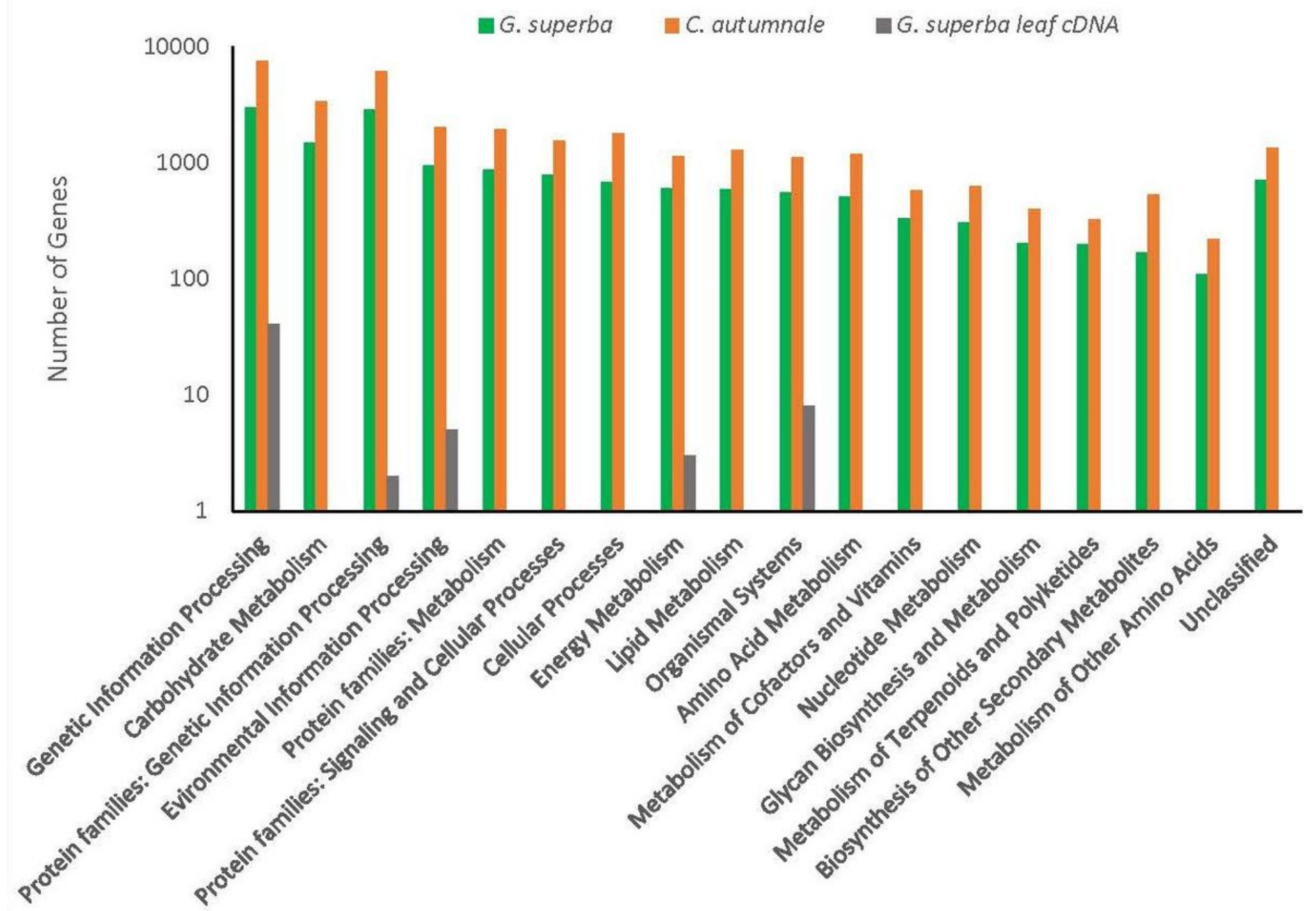

Pathway Categories

Figure 4

Kyoto Encyclopedia of Genes and Genomes (KEGG) annotation of G. superba and C. autumnale transcriptomes and G. superba leaf cDNA library predicted proteins. 


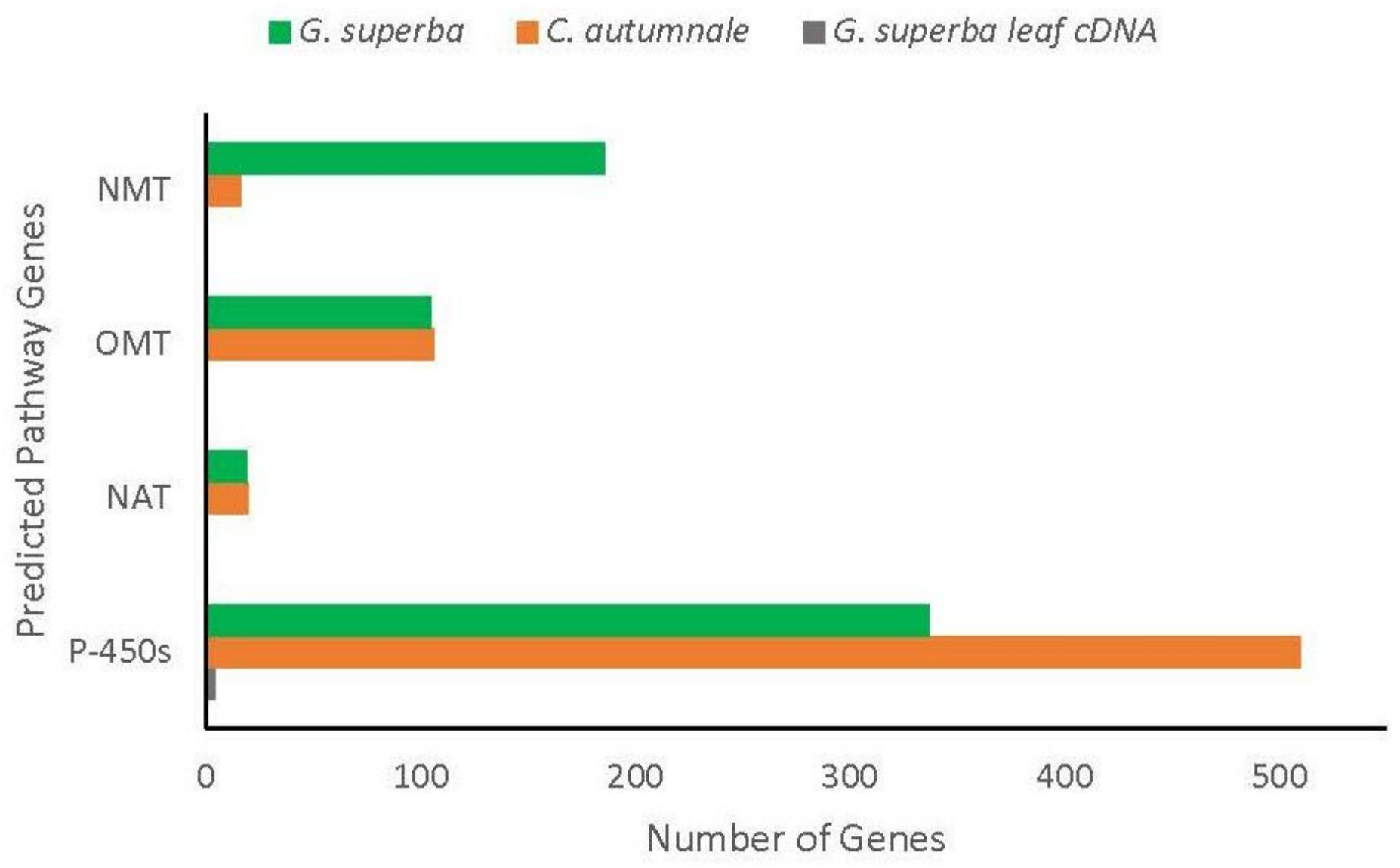

Figure 5

Total number of transcripts in colchicine pathway in G. superba and C. autumnale transcriptomes and G. superba leaf cDNA library. 
G. superba C. autumnale $\square$ G. superba leaf cDNA $\square$ S. tuberosum $\mathbf{N}$. nucifera

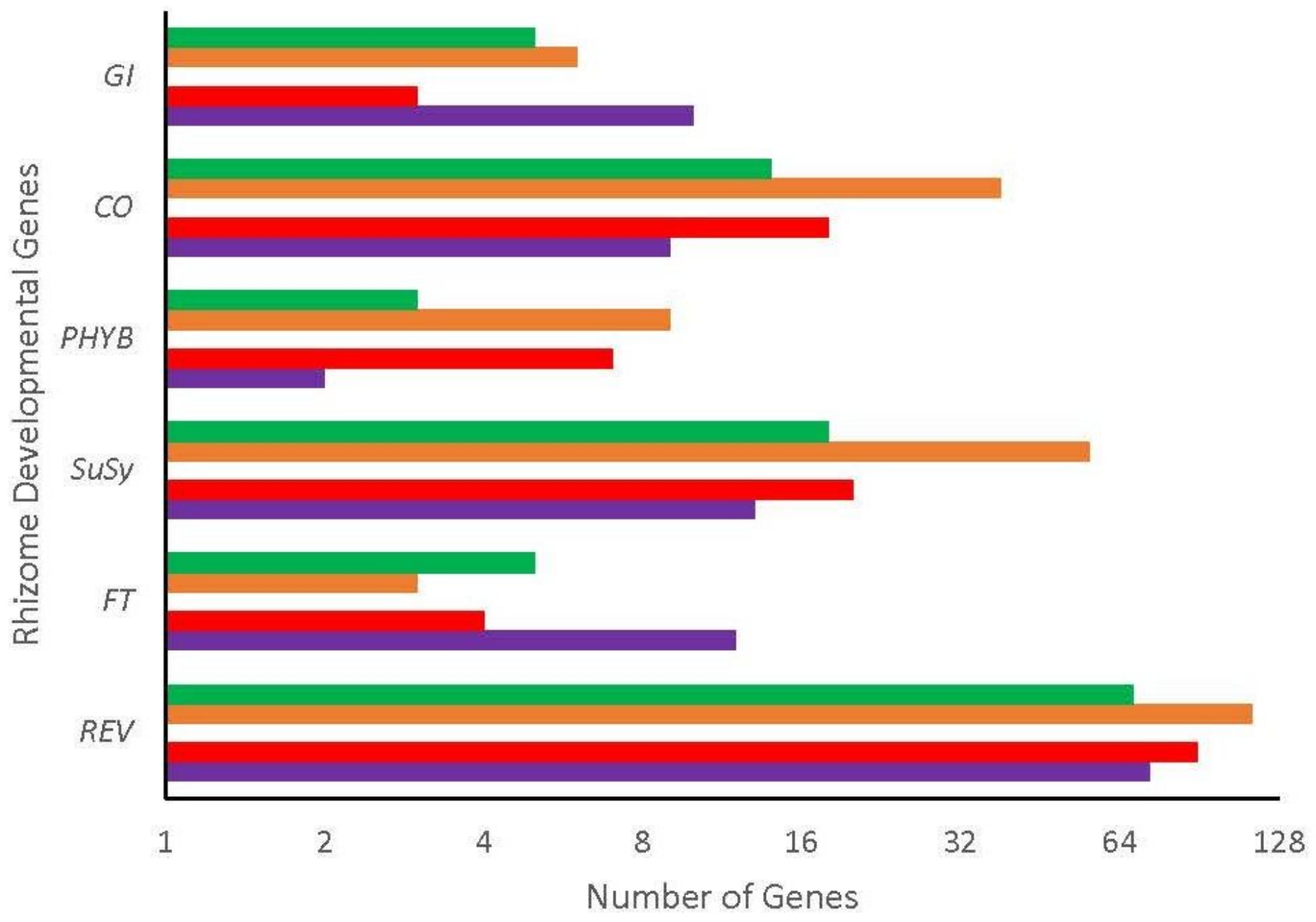

Figure 6

Total number of transcripts of rhizome developmental genes in G. superba and C. autumnale transcriptomes and G. superba leaf cDNA library. Solanum tuberosum and Nelumbo nucifera were reference transcriptomes. 


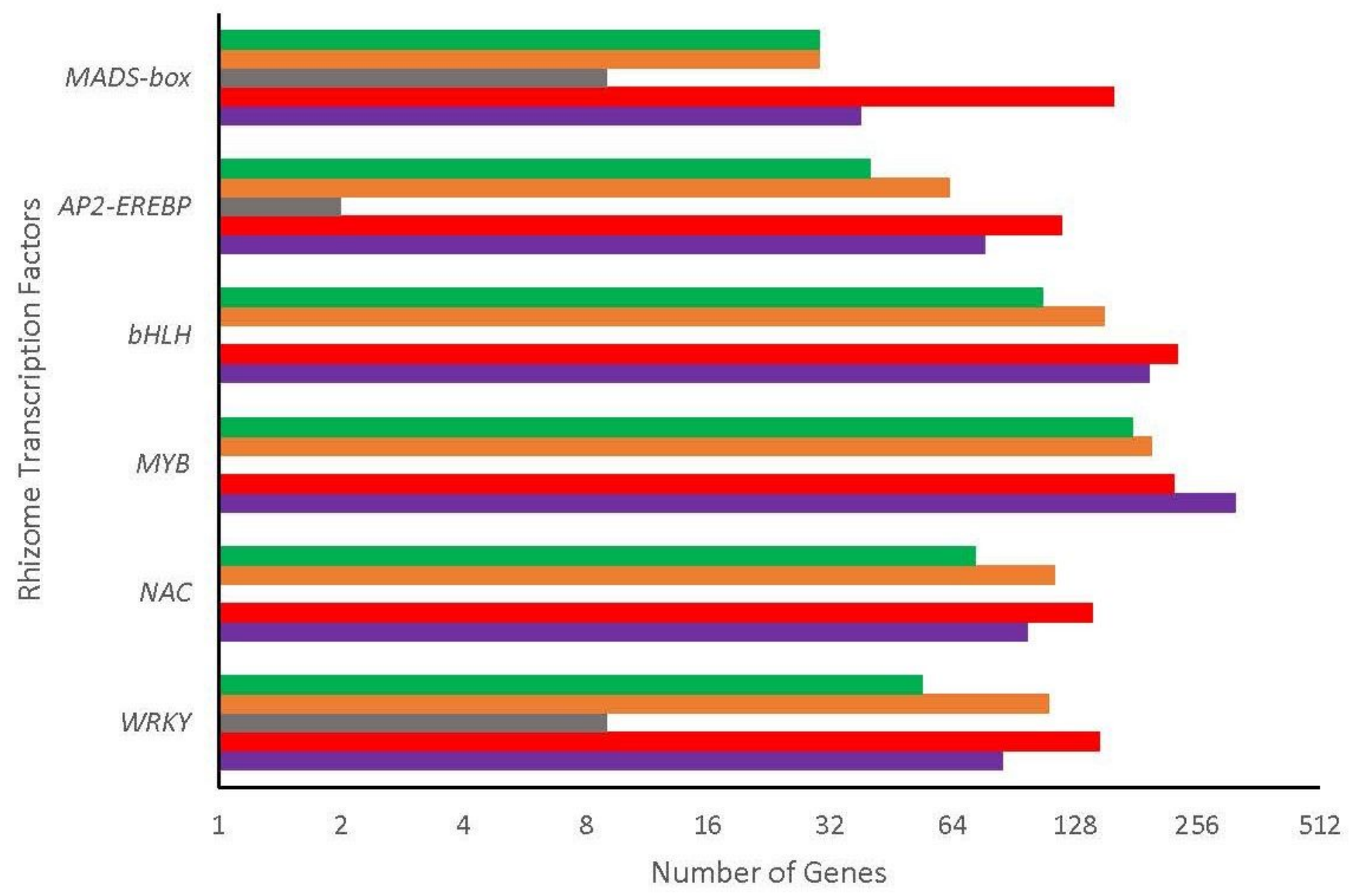

Figure 7

Total number of transcripts of transcription factors in G. superba and C. autumnale transcriptomes and G. superba leaf cDNA library. S. tuberosum and N. nucifera were reference transcriptomes. 


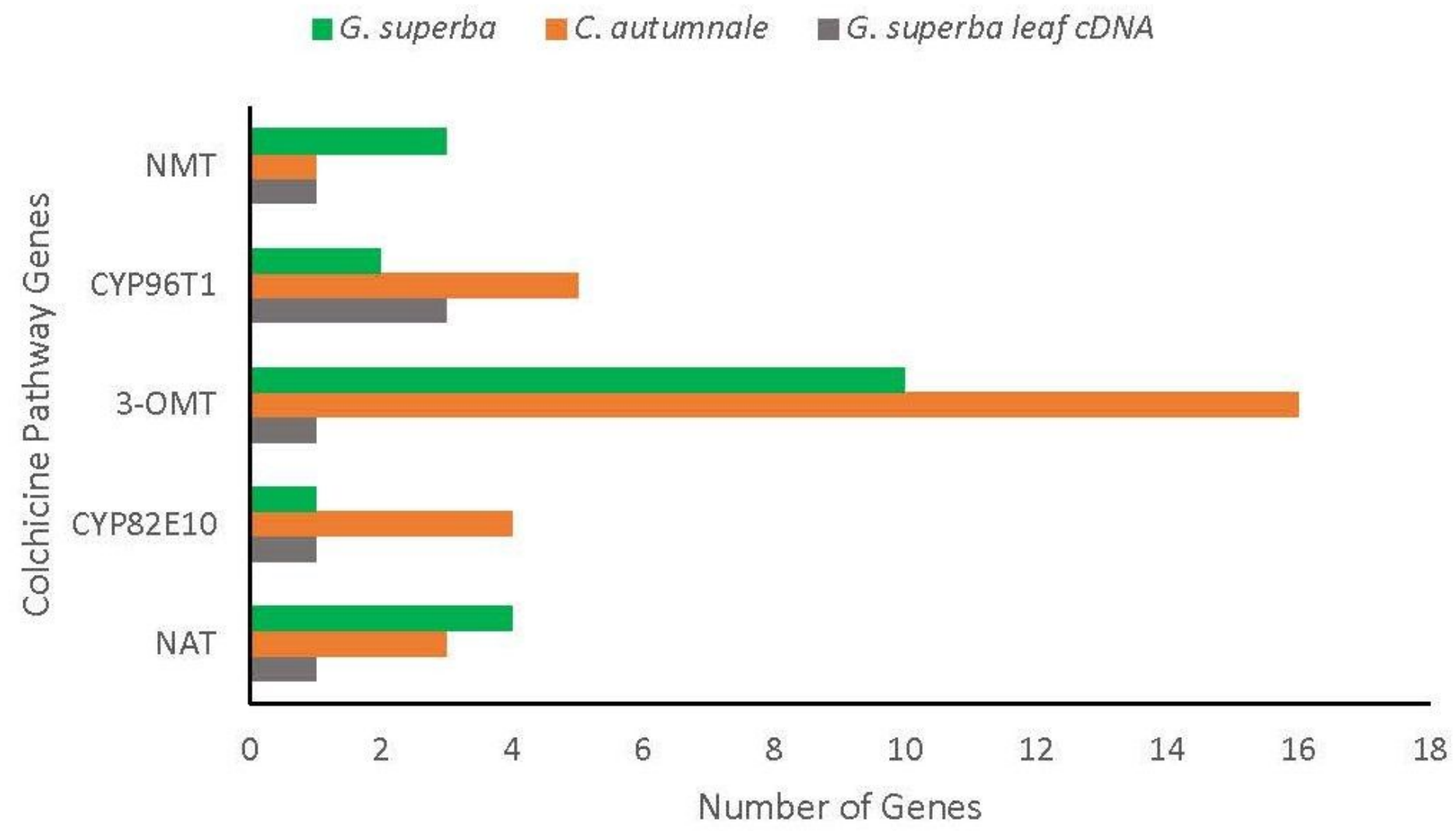

\section{Figure 8}

Possible candidate colchicine pathway genes in G. superba and C. autumnale transcriptomes and G. superba leaf cDNA library. 
G. superba C. autumnale

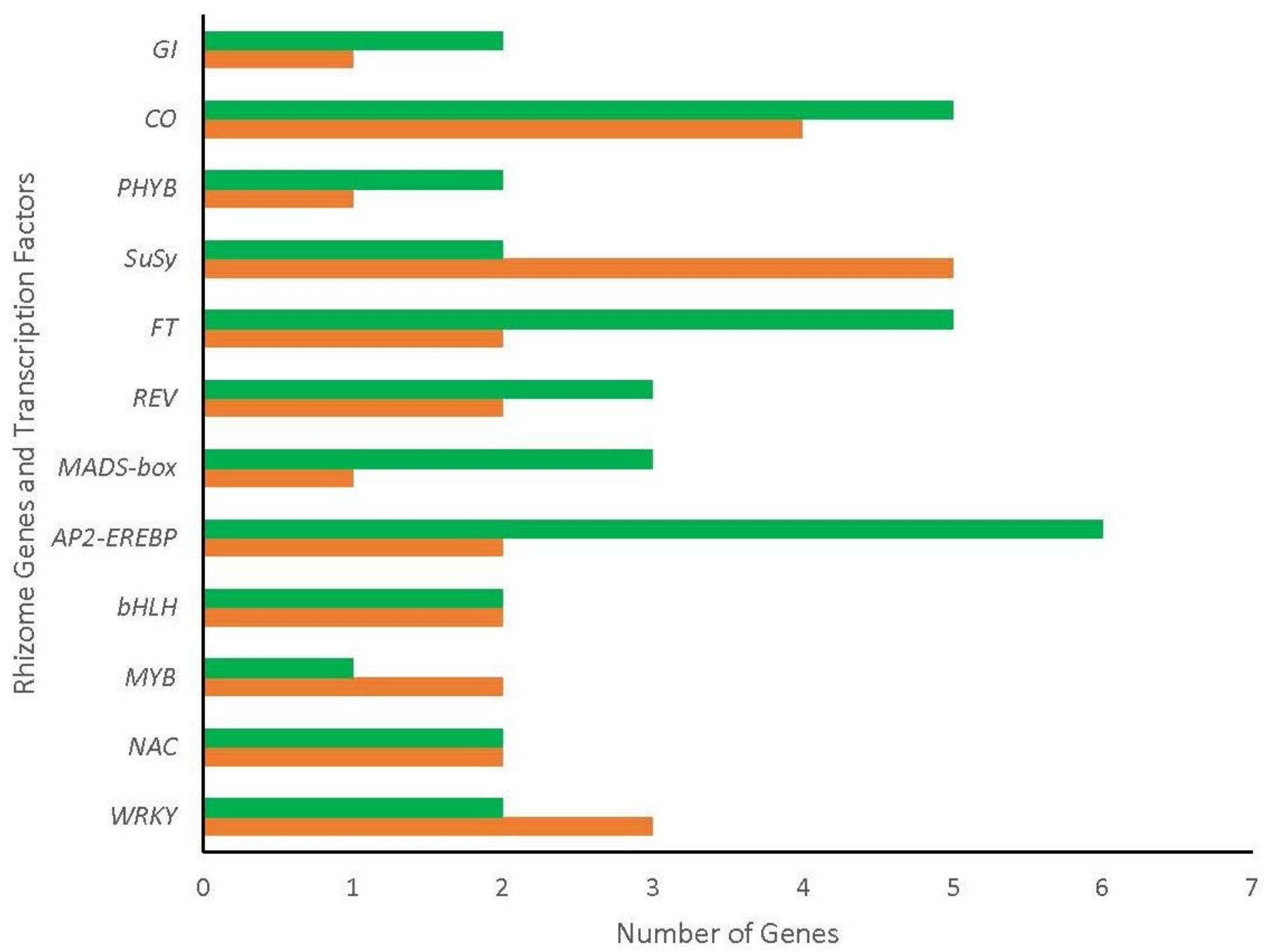

Figure 9

Possible candidate rhizome developmental genes and transcription factors in G. superba and C. autumnale transcriptomes. 

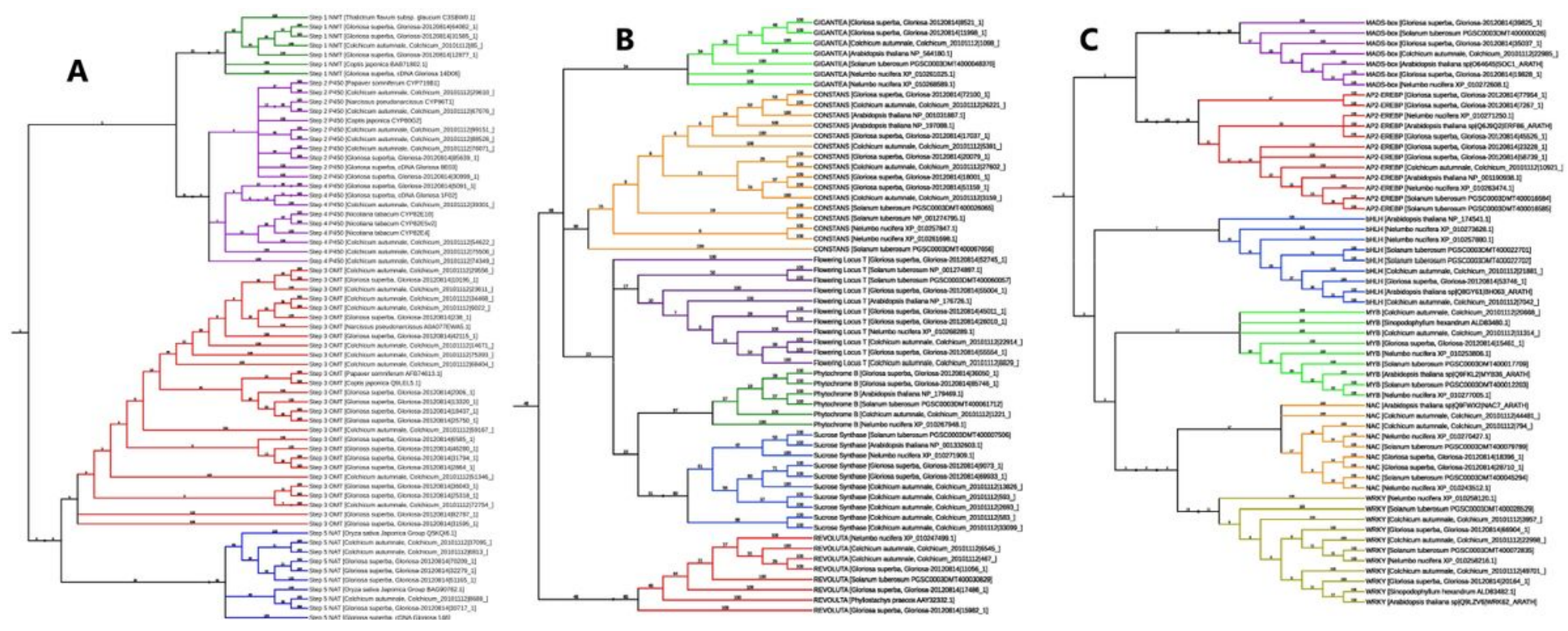

Figure 10

A. Predicted colchicine pathway phylogenetic tree of G. superba and C. autumnale transcriptomes with reference genes. Neighbor-joining tree of pathway enzymes shown with NMT, P450s, OMT, and NAT was generated from PHYLIP-3.697 software suite with 1000 replicates in bootstrap values. B. Neighbor-joining phylogenetic tree of rhizome developmental genes in $\mathrm{G}$. superba and $\mathrm{C}$. autumnale transcriptomes with reference genes from S. tuberosum, N. nucifera, A. thaliana, and P. praecox. The phylogenetic relationship of GI, CO, FT, PHYB, SuSy, and REV were generated from the PHYLIP-3.697 package with 1000 replicates in bootstrap values. C. Phylogenetic tree of rhizome transcription factors such as MADS-box, AP2-EREBP, bHLH, MYB, NAC, and WRKY in G. superba and C. autumnale transcriptomes with reference genes from S. tuberosum, N. nucifera, A. thaliana, and S. hexandrum. The phylogenetic relationship were conducted from the PHYLIP-3.697 package with 1000 replicates in bootstrap values. 